\title{
UNIVERSITY OF TEXAS AT AUSTIN RADIOCARBON DATES XI
}

\author{
S VALASTRO, JR, E MOTT DAVIS, \\ and ALEJANDRA G VARELA
}

\section{Radiocarbon Laboratory, Balcones Research Center,}

The University of Texas at Austin

This list reports ${ }^{14} \mathrm{C}$ measurements completed between August 1973 and November 1975. Other projects completed in that period will be reported later. Age calculations are based on ${ }^{14} \mathrm{C}$ half-life of $5568 \mathrm{yr}$ and modern standard of $95 \%$ NBS oxalic acid, supplemented by tree rings of pre-industrial wood from a log cut in the 1850's (Tx-540; R, 1970, v 12, p 249). Deviations reported are based on counting statistics of sample, background, and modern, and are $\pm 1_{\sigma}$, except that when sample count approaches either modern or background, $2 \sigma$ limits are reported. Unless noted, ${ }^{12} \mathrm{C} /{ }^{13} \mathrm{C}$ measurements were not made and results are not corrected for ${ }^{13} \mathrm{C}$ fractionation. The laboratory uses liquid scintillation counting of benzene, with $\mathrm{Li}_{2} \mathrm{C}_{2}$ and vanadium-activated catalyst in preparation; chemical yields range between $95 \%$ and $99 \%$. Three counters are employed: a Packard Tri-Carb Model 3002, and 2 Beckman LS-230 spectrometers obtained through a grant from the National Science Foundation.

We acknowledge with gratitude the assistance of Carolyn Good in preparing the date list, and the administrative support and assistance of W W Newcomb and Saralind Mings of the Texas Memorial Museum.

I. GEOLOGIC, OCEANOGRAPHIC, AND PALEONTOLOGIC SAMPLES

\section{Lower Gulf Coast, Texas}

Samples from cores taken along lower Gulf Coast of Texas. Coll 1970-1971 and subm by E W Behrens, Univ Texas Marine Sci Inst, Port Aransas, Texas. In titles, no. after core no. is distance in $\mathrm{cm}$ below top of core.

Tx-1362. Baffin Bay, several cores

$1590 \pm 100$

Marl from several cores in different locations in Baffin Bay, 50 to $100 \mathrm{~cm}$ below top of cores. Should date algal mat sequence found in many of the cores.

\section{Baffin Bay Core 6 series}

Samples from Core $6,1.7 \mathrm{~km} \mathrm{~S}$ of Marker $68,2.8 \mathrm{~km} \mathrm{~S}$ of Kleberg

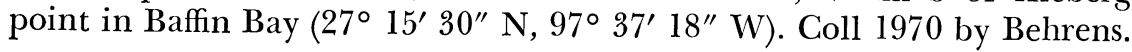

Tx-1363. Baffin Bay 6, 486 to $497 \quad 3550 \pm 80$

Dolomite.

Tx-1364. Baffin Bay 6, 556 to $558 \quad 4000 \pm 90$

Calcium carbonate mud, shell, and dolomite. 
Tx-1365. Baffin Bay 6, 608 to 617

$4010 \pm 90$

Dolomite.

Baffin Bay Core 27 series

Samples from Core 27, 2.4km SW of E Kleberg Point in Baffin Bay (27 $\left.15^{\prime} 24^{\prime \prime} \mathrm{N}, 97^{\circ} 31^{\prime} 24^{\prime \prime} \mathrm{W}\right)$. Coll 1971 by Behrens.

Tx-1384. Baffin Bay 27, 655 to $657 \quad 3910 \pm 90$

Dolomite.

Tx-1385. Baffin Bay 27, 608 to 613 $3790 \pm 90$

Dolomite.

Tx-1386. Baffin Bay 27, 696 to 697

$3960 \pm 100$

Dolomite.

Tx-1387. Baffin Bay 27, 436 to 438

$3220 \pm 80$

Dolomite.

Tx-1389. Baffin Bay 27, 45 to 65

$1920 \pm 90$

Core mud.

Laguna Salada Core 8 series

Samples from Core $8,1.9 \mathrm{~km} \mathrm{~S}$ of Riviera Beach in Laguna Salada (27 $\left.16^{\prime} 12^{\prime \prime} \mathrm{N}, 97^{\circ} 40^{\prime} 30^{\prime \prime} \mathrm{W}\right)$. Coll 1971 by Behrens.

Tx-1366. Laguna Salada 8, 185 to $205 \quad 3290 \pm 80$

Anomalocardia cuniemeris shell hash.

Tx-1367. Laguna Salada 8, 205 to $235 \quad 3960 \pm 90$

Anomalocardia cuniemeris shell hash.

Laguna Salada Core 10 series

Samples from Core 10, $3 \mathrm{~km}$ SE of Williamson's Boat Basin in Laguna Salada $\left(27^{\circ} 16^{\prime} 30^{\prime \prime} \mathrm{N}, 97^{\circ} 40^{\prime} 42^{\prime \prime} \mathrm{W}\right)$. Coll 1971 by Behrens.

Tx-1368. Laguna Salada 10, 415

$4030 \pm 90$

Blebby carbonate mud.

Tx-1369A. Laguna Salada 10, 425(a)

$3880 \pm 90$

Dolomite. Portion selected from larger sample.

Tx-1369B. Laguna Salada 10, 425(b) $4390 \pm 80$

As with Tx-1369A, but large sample mixed thoroughly before removal of smaller sample for dating. Comment (EWB): average of Tx$1369 \mathrm{~A}$ and $-1369 \mathrm{~B}$ gives most reasonable result.

Tx-1370. Laguna Salada 10, 498 to $517 \quad 4500 \pm 90$

Taxonomically diverse shell hash.

Tx-1371. Laguna Salada 10, 525 to $550 \quad 5500 \pm 90$

Taxonomically diverse shell hash. 
Tx-1372. Laguna Salada 10, 555 to 575 $5760 \pm 80$

Taxonomically diverse shell hash.

Tx-1373. Laguna Salada 10, 590 to 606

$6600 \pm 120$

Taxonomically diverse shell hash.

Cayo del Grullo Core 20 series

Samples from Core 20, $2.2 \mathrm{~km}$ SE of T-head pier at Loyola Beach

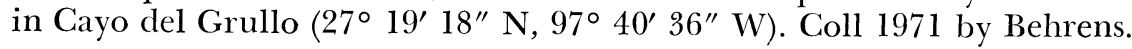

Tx-1374. Cayo del Grullo 20, 45 to $55 \quad 2390 \pm 90$

Anomalocardia cuniemeris shell hash.

Tx-1375. Cayo del Grullo 20, 85 to $100 \quad 3410 \pm 70$

Anomalocardia cuniemeris shell hash.

Tx-1376. Cayo del Grullo 20,125 to $150 \quad 3880 \pm 90$

Anomalocardia cuniemeris shell hash-carbonate rock.

Tx-1377A. Cayo del Grullo 20, 225 to 238(a) $7520 \pm 130$

Core mud; portion selected from large sample without mixing.

Tx-1377B. Cayo del Grullo 20, 225 to 238(b) $\quad 10,030 \pm 140$

As with Tx-1377A, but large sample first completely mixed before removal of portion for dating.

Tx-1378A. Cayo del Grullo 20, 305 to $317 \quad 7300 \pm 130$

Core mud; portion selected from large sample without mixing.

Tx-1378B. Cayo del Grullo 20, 305 to $317 \quad 10,816 \pm 120$

As with Tx-1378A, but large sample completely mixed before removal of portion for dating.

Tx-1379. Cayo del Grullo 20, 265 to $280 \quad 5340 \pm 100$

Taxonomically diverse shell hash.

Tx-1380. Cayo del Grullo 20,365 to $380 \quad 5670 \pm 110$

Taxonomically diverse shell hash.

Tx-1401. Cayo del Grullo 20, 362 to $365 \quad 5560 \pm 100$

Taxonomically diverse shell hash.

\section{Cayo del Grullo Core 21 series}

Samples from Core 21, 2.2km SE of T-head pier at Loyola Beach

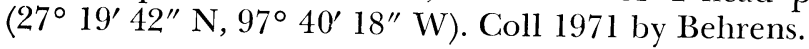

Tx-1381. Cayo del Grullo 21, 608 to 644

Taxonomically diverse shell hash.

$6560 \pm 120$

Tx-1382. Cayo del Grullo 21, 542 to 600

Taxonomically diverse shell hash. 
Tx-1383. Cayo del Grullo 21, 492 to 542

Taxonomically diverse shell hash; carbonate rock.

Tx-1388. Cayo del Grullo 21, 400 to 450

$\mathbf{5 0 5 0} \pm \mathbf{1 0 0}$

Taxonomically diverse shell hash.

Tx-1392. Cayo del Grullo 21, 145 to 155

$2870 \pm 80$

Anomalocardia cuniemeris shell hash; carbonate rock.

Tx-1393. Cayo del Grullo 21, 233 to 265

$3960 \pm 90$

Anomalocardia cuniemeris shell hash.

Tx-1394. Cayo del Grullo 21, 115 to 137

$2560 \pm 80$

Anomalocardia cuniemeris shell hash.

Tx-1402. Cayo del Grullo 21, 63 to 94

$1900 \pm 70$

Anomalocardia cuniemeris shell hash.

General Comment (EWB): dates establish compatibility of varied carbonate materials for dating. Age increases with depth irrespective of material; exception is $\mathrm{CaCO}_{3}$ mud finely disseminated through cores, which apparently has significant amount of detrital dead C, giving anomalously great ages (eg Tx-1377, -1378).

Dates indicate that to determine sedimentation rates, age separation of 2 samples need not be greater than combined $l_{\sigma}$ values of the 2 dates, but should be no smaller than $l_{\sigma}$ of either date. All pairs of samples separated by at least $100 \mathrm{yr}$ give sedimentation rates comparing well (within $2 \sigma$ ) with rates calculated from all pairs with age separation greater than combined $l_{\sigma}$ values of the pair.

Period of dolomite deposition from 2300 to $4300 \mathrm{BP}$, previously determined (Behrens \& Land, 1972), is supported by present data. Present dates Tx-1363-1365, -1369, -1384-1387 suggest more active deposition in 1st half of this period.

Transition from open marine to closed hypersaline environment, previously dated 3500 to $5000 \mathrm{BP}$ (Rusnak, 1960), is indicated by change from taxonomically diverse shell assemblage to restricted assemblage strongly dominated by Anomalocardia cuniemeris. Dolomite beds could probably form only after restriction began. Present dates indicate major change was between 4400 and $3600 \mathrm{BP}$; essentially modern conditions have prevailed since ca $4000 \mathrm{BP}$.

\section{Other Gulf Coast, Texas, Samples}

\section{Packery Channel series}

Samples from area of Packery Channel, Newport Channel, and Corpus Christi Channel, Mustang I., E of Corpus Christi, lower Texas Gulf Coast. Coll 1972 (except as noted) and subm by J H McGowen, Bur Econ Geol, Univ Texas, Austin. Nos. after sample title denote depth in $\mathrm{ft}$ below surface. 
Tx-1616. Packery Channel Hole 4, 15 to $17.5 \quad 4470 \pm 110$

Anomalocardia cuneimeris from drill hole, depth 4.6 to $5.3 \mathrm{~m}$, ca $10 \mathrm{~m}$ from $\mathrm{E}$ bank of Packery Channel, in bare flat, ca $700 \mathrm{~m} \mathrm{~W}$ of Gulf beach and $1.5 \mathrm{~km} \mathrm{~N}$ of Nueces Co Park \#1 (27 $\left.36^{\prime} 50^{\prime \prime} \mathrm{N}, 97^{\circ} 12^{\prime} 17^{\prime \prime} \mathrm{W}\right)$. Holocene bay margin, grass flat sediment.

Tx-1617. Packery Channel Hole 2, 7.5 to 10

$730 \pm 90$

Plant debris from drill hole, depth 2.3 to $3 \mathrm{~m}$, ca $10 \mathrm{~m} \mathrm{~S}$ of Newport Channel, ca $550 \mathrm{~m} \mathrm{~W}$ of Gulf beach and $2 \mathrm{~km} \mathrm{~N}$ of Nueces Co Park \#1 $\left(27^{\circ} 36^{\prime} 50^{\prime \prime} \mathrm{N}, 97^{\circ} 12^{\prime} 45^{\prime \prime} \mathrm{W}\right)$, in edge of vegetated barrier flat. Holocene barrier sediment. Adjacent to recent storm channel; materials may be mixed.

Tx-1619. Packery Channel Hole 2, 10 to $12.5 \quad 1100 \pm 60$

Wood fragments, as with Tx-1617, depth 3.0 to $3.7 \mathrm{~m}$.

Tx-1618. Packery Channel Hole 2,45 to $50 \quad 1670 \pm 120$

Wood fragments, as with Tx-1617, depth 13.7 to $15.2 \mathrm{~m}$. Sample was well below any existing recent channel and should represent initial valleyfill assoc with stillstand.

Tx-1685. Packery Channel \#7, 17.5 to $20 \quad 1690 \pm 50$

Shell (Donax) from beach, depth 5.3 to $6.1 \mathrm{~m}, 600 \mathrm{~m}$ NE of Corpus

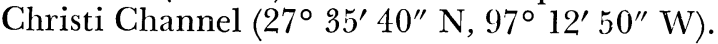

Tx-1686. Packery Channel \#8, 17.5 to $20 \quad 990 \pm 240$

Wood fragments from beach, depth 5.3 to $6.1 \mathrm{~m}, 600 \mathrm{~m}$ NE of Corpus Christi Channel (27 $36^{\prime} 30^{\prime \prime}$ N, $\left.97^{\circ} 12^{\prime} 25^{\prime \prime} \mathrm{W}\right)$.

Tx-1687. Packery Channel \#9, 20 to 22.5

$310 \pm 70$

Wood fragments from beach, depth 6.1 to $6.8 \mathrm{~m}, 750 \mathrm{~m}$ SW of Packery Channel (27० $\left.36^{\prime} 25^{\prime \prime} \mathrm{N}, 97^{\circ} 12^{\prime} 20^{\prime \prime} \mathrm{W}\right)$.

Tx-1688. Packery Channel \#10W, 15 to $17.5 \quad 1250 \pm 380$

Wood fragments from beach in mouth of Packery Channel $\left(27^{\circ} 36^{\prime}\right.$ $40^{\prime \prime} \mathrm{N}, 97^{\circ} 12^{\prime} 15^{\prime \prime} \mathrm{W}$ ), depth 4.6 to $5.3 \mathrm{~m}$.

Tx-1689. Packery Channel \#11, 20 to $22.5 \quad 2880 \pm 170$

Wood fragments, depth 6.1 to $6.8 \mathrm{~m}, 600 \mathrm{~m}$ NW of beach midway between Packery and Corpus Christi Channels (27 $36^{\prime} 30^{\prime \prime}$ N, $97^{\circ} 12^{\prime}$ $\left.40^{\prime \prime} \mathrm{W}\right)$.

Tx-1690. Packery Channel \#12, 10 to $12.5 \quad 1000 \pm 170$

Wood fragments from $360 \mathrm{~m} \mathrm{NW}$ of beach, depth 3.0 to $3.8 \mathrm{~m}$, midway between Packery and Corpus Christi Channels (27 $36^{\prime} 20^{\prime \prime} \mathrm{N}, 97^{\circ} 12^{\prime}$ $\left.40^{\prime \prime} \mathrm{W}\right)$.

Tx-1691. Packery Channel \#13W, 12.5 to $15 \quad 1780 \pm 120$

Wood chips from beach midway between Packery and Corpus Christi Channels (27० $\left.36^{\prime} 20^{\prime \prime} \mathrm{N}, 97^{\circ} 12^{\prime} 25^{\prime \prime} \mathrm{W}\right)$, depth 3.8 to $4.6 \mathrm{~m}$. 
Tx-1692. Packery Channel \#15A, 15 to $17.5 \quad 5400 \pm 80$

Shell (Anomalocardia), from $900 \mathrm{~m} \mathrm{~N}$ of beach, depth 4.6 to $5.3 \mathrm{~m}$, directly up Corpus Christi Channel (27० $\left.36^{\prime} 15^{\prime \prime} \mathrm{N}, 97^{\circ} 12^{\prime} 55^{\prime \prime} \mathrm{W}\right)$.

Tx-1693. Packery Channel \#15M, 15 to $17.5 \quad 5410 \pm 240$

Shell (Malinia), depth 4.6 to $5.3 \mathrm{~m}$, same location as Tx-1692, above.

Tx-1694. Packery Channel \#13E, 12.5 to $15 \quad 2530 \pm 70$

Shell and mostly echinoid debris, depth 3.8 to $4.6 \mathrm{~m}$, same location as Tx-1691, above.

Tx-1695. Packery Channel \#10M, 15 to $17.5 \quad 2580 \pm 150$

Shell (Malinia), depth 4.6 to $5.3 \mathrm{~m}$, same area as Tx-1688, above.

Tx-1696. Packery Channel \#10D, 15 to $17.5 \quad 950 \pm 90$

Shell (Donax), depth 4.6 to $5.3 \mathrm{~m}$, same site as Tx-1688, above.

Tx-1697. Packery Channel \#5, 17.5 to $20 \quad 2400 \pm 70$

Mostly echinoid shell debris, depth 5.3 to $6.1 \mathrm{~m}, 300 \mathrm{~m}$ NW of beach in Corpus Christi Channel (27 $36^{\prime} 05^{\prime \prime} \mathrm{N}, 97^{\circ} 12^{\prime} 45^{\prime \prime} \mathrm{W}$ ).

Tx-1737. Packery Channel \# 17, 25 to $27 \quad 850 \pm 170$

Wood fragment from middle of storm channel, depth 7.6 to $7.9 \mathrm{~m}$, $3.5 \mathrm{~km} \mathrm{~N}$ of Bob Hall Pier, ca $30 \mathrm{~m}$ from swash zone $\left(27^{\circ} 36^{\prime} 48^{\prime \prime} \mathrm{N}, 97^{\circ}\right.$ 12' 07" W). Coll 1973.

Tx-1738. Packery Channel \#10, 16 to $17 \quad 3520 \pm \mathbf{2 5 0}$

Washed wood from right bank of present storm channel, depth 4.9 to $5.2 \mathrm{~m}$, Newport Channel, $3.3 \mathrm{~km} \mathrm{~N}$ of Bob Hall Pier, ca $30 \mathrm{~m}$ from

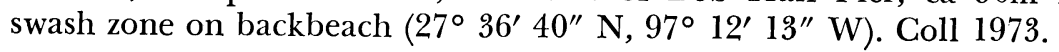

Tx-1739. Packery Channel \#18A, 24 to $27 \quad 1320 \pm 80$

Washed shell (Donax) from left bank of storm channel, depth 7.3 to $8.2 \mathrm{~km} \mathrm{~N}$ of Bob Hall Pier, $30 \mathrm{~m}$ from swash zone $\left(27^{\circ} 37^{\prime} \mathrm{N}, 97^{\circ} 12^{\prime}\right.$ 03" W). Coll 1973.

Tx-1740. Packery Channel \# 18B, 24 to $27 \quad 2450 \pm 100$ above.

Washed shell (Mulinia), depth 7.3 to $8.2 \mathrm{~m}$, same core as Tx-1739,

Tx-1741. Packery Channel \#17, 20 to 21

Washed shell (Donax), depth 6.1 to $6.4 \mathrm{~m}$, coll 1973 .

$1200 \pm 90$

General Comment (JHMCG): dates provide chronology of development of $\mathrm{N}$ part of Padre I. and evolution of tidal channel between Mustang and Padre Is. These dates aided Texas State Land Office in settling a legal dispute, permitting the state to retain ownership of this segment of coastal lands.

\section{Lavaca Bay series}

Wood and plant debris samples from Sites L-55 $\left(28^{\circ} 35^{\prime} 40^{\prime \prime} \mathrm{N}\right.$, $\left.96^{\circ} 30^{\prime} 35^{\prime \prime} \mathrm{W}\right)$ and L-57 (28 34' $\left.55^{\prime \prime} \mathrm{N}, 96^{\circ} 30^{\prime} 10^{\prime \prime} \mathrm{W}\right)$ in Lavaca Bay, 
Central Gulf coast of Texas. Dated to estimate age of aggradation of Lavaca $\mathrm{R}$ and oldest age of bay mud. Coll 1973 by B Wilkinson and J R Byrne and subm by Byrne, Dept Geol Sci, Univ Texas, Austin. In sample titles, figures refer to depth in meters below present sea level.

Comments by Byrne.

Tx-1805. Lavaca Bay, L-55, 22.8 to $24.3 \quad 9580 \pm 760$

Comment: start of marine inundation of Lavaca-Navidad Estuary $9430 \pm 100 \mathrm{BP}$.

Tx-1806. Lavaca Bay, L-55, 22.5

$8300 \pm 180$

Comment: all mud is recent.

Tx-1808. Lavaca Bay, L-55, 25.8 to $27.4 \quad 10,120 \pm 3500$

Comment: ages and depths agree with pub sea level curves for Holocene.

Tx-1980. Lavaca Bay, L-57, 25.8

$9430 \pm 100$

Tx-1982. Lavaca Bay, L-55, 2.4 to 3.3

$2190 \pm 60$

Comment: ages from deltaic (Holocene) beds decrease in age landward. Lavaca-Navidad fluvial-deltaic complex migrated upvalley in response to rising sea level.

\section{Matagorda, Cunningham series}

Samples of oyster shell from area of Matagorda Peninsula, Holocene barrier i. on Texas gulf coast SW of Houston. Coll 1971 and subm by J D Cunningham, Bur Econ Geol, Univ Texas at Austin, unless otherwise stated.

Tx-1287. Matagorda 35/X

$28,490 \pm 1210$

From Pleistocene oyster reef (alt not known) on E side of Texas Hwy 35, Carancahua Bay, Jackson Co, ca $2.4 \mathrm{~km} \mathrm{E}$ of Hwy 35 and Hwy 172 intersection $\left(28^{\circ} 43^{\prime} \mathrm{N}, 96^{\circ} 26^{\prime} \mathrm{W}\right)$. Will give ref date of known Pleistocene reef. Coll 1971 by J H McGowen.

\section{Tx-1284. Matagorda SBR/X}

$1150 \pm 70$

From growth position ca $0.6 \mathrm{~m}$ below ground level at junction of San Bernard R and Intracoastal Waterway (28 $\left.52^{\prime} \mathrm{N}, 95^{\circ} 27^{\prime} \mathrm{W}\right)$. Coll 1971 by J H McGowen.

Tx-1291. Matagorda 1/AS

$2480 \pm 80$

From reef exposed in swash zone, $16.8 \mathrm{~km} \mathrm{E}$ of Sargent's Beach Rd, adjacent to $\mathrm{W}$-most lake of Cedar Lakes group ( $\left.28^{\circ} 51^{\prime} \mathrm{N}, 95^{\circ} 28^{\prime} \mathrm{W}\right)$.

Tx-1290. Matagorda 2/FS

$860 \pm 70$

From swash zone at base of forebeach in growth position $10.2 \mathrm{~km}$ E of Sargent's Beach Rd, S of Choctaw Lake (28 $\left.49^{\prime} \mathrm{N}, 95^{\circ} 31^{\prime} \mathrm{W}\right)$.

\section{Tx-1338. Matagorda A/AS}

$\mathbf{5 7 0 0} \pm 90$

Abraded shell from shoreface near storm channel SW of Brown Cedar Cut $\left(28^{\circ} 43^{\prime} \mathrm{N}, 95^{\circ} 42^{\prime} \mathrm{W}\right)$. 
Tx-1337. Matagorda A/FS

$4040 \pm 80$

Same as Tx-1338, above.

Tx-1281. Matagorda A/AB

$3990 \pm 80$

Same as Tx-1338, above.

Tx-1283. Matagorda AA/AS

$2030 \pm 80$

From shoreface erosional scarp in forebeach $\left(28^{\circ} 42^{\prime} \mathrm{N}, 95^{\circ} 44^{\prime} \mathrm{W}\right)$.

Tx-1282. Matagorda AA/FS

$11,190 \pm 160$

Same as Tx-1283, above.

Tx-1286. Matagorda AA/AB

$6170 \pm 100$

Same as Tx-1283, above.

Tx-1289. Matagorda AA/FB

$4140 \pm 80$

Same as Tx-1283, above.

Tx-1288. Matagorda E/AS

$6720 \pm 100$

From shoreface, E Point triangulation sta $\left(28^{\circ} 41^{\prime} \mathrm{N}, 95^{\circ} 46^{\prime} \mathrm{W}\right)$.

Tx-1285. Matagorda E/FS

$37,130 \pm 3110$

Same as Tx-1288, above. Should date eroding material, date of existence of bay.

Tx-1292. Matagorda E/AB

$15,620 \pm 250$

Same as Tx-1288, above. Should give date of reworked shell material from high energy environment, and date of bay's existence.

\section{Tx-1293. Matagorda E/FB}

$5140 \pm 100$

Same as Tx-1288, above. Should determine date of eroding bay materials.

General Comment (JHMcG): dates show that shell and most of sand making up Gulf shoreline features between San Bernard and Colorado $\mathrm{R}$ is derived from Pleistocene and Holocene deposits that are being eroded from shoreface and inner continental shelf. ${ }^{14} \mathrm{C}$ dates were used to determine sediment source for shoreline features, direction of sediment transport, and relative rates of subsidence and shoreline retreat prior to historical times.

\section{Matagorda, Wilkinson series}

Samples from various locations on Matagorda I. and Peninsula, S central Gulf Coast of Texas, coll and subm 1972, 1975 by B H Wilkinson, Dept. Geol \& Min, Univ Michigan, Ann Arbor (Wilkinson, 1973). In sample titles, lst letter or no. is designation of drill hole; following nos. are depths in $\mathrm{ft}$ below ground surface.

Tx-1580. Matagorda $D, 39$

$\delta^{14} \mathrm{C}=+\mathbf{6 0 . 6 7} \pm \mathbf{1 2 . 1} \%$

Wood fragments from base of gray clay unit, depth $11.7 \mathrm{~m}, \mathrm{E}$ end Matagorda I. 80m from Pass Cavallo next to "Fish Pond" (28 22' 30" N, 
$\left.96^{\circ} 22^{\prime} 30^{\prime \prime} \mathrm{W}\right)$. Comment (BHW): obviously not of use. Reason for anomalous age not known.

Tx-1581. Matagorda MM, 25 to 30

$4490 \pm 230$

Plant fragments, depth 7.6 to $9 \mathrm{~m}$, S end Matagorda I. $0.8 \mathrm{~km}$ SW of

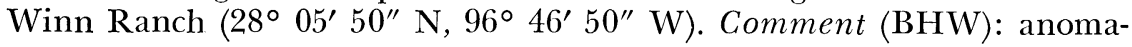
lously old; not of use in analysis.

Tx-1582. Matagorda J, 15 to $20 \quad 2620 \pm 70$

Shell (Donax \& Malinia), depth 4.6 to $6 \mathrm{~m}$, E end Matagorda I. $1.2 \mathrm{~km}$ $\mathrm{S}$ of Lighthouse Cove $\left(28^{\circ} 21^{\prime} \mathrm{N}, 96^{\circ} 25^{\prime} 05^{\prime \prime} \mathrm{W}\right)$.

Tx-1583. Matagorda II, 15 to 20

$2360 \pm 60$

Shell (Donax \& Malinia), depth 4.6 to $6 \mathrm{~m}, \mathrm{~S}$ central portion of

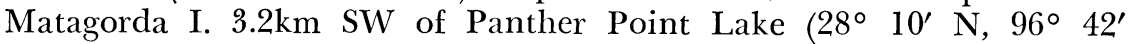
$\left.25^{\prime \prime} \mathrm{W}\right)$.

Tx-1584. Matagorda $A, 15$ to 20

$5720 \pm 90$

Shell (Donax \& Malinia), depth 4.6 to $6 \mathrm{~m}, \mathrm{~N}$ end Matagorda I. $0.4 \mathrm{~km}$ NE of Matagorda I. Air Force Base $\left(28^{\circ} 20^{\prime} \mathrm{N}, 96^{\circ} 26^{\prime} \mathrm{W}\right)$.

Tx-1585. Matagorda $T, 10$ to 15

$5360 \pm 80$

Shell (Donax \& Malinia), depth 3 to $4.6 \mathrm{~m}$, center Matagorda I. $3.2 \mathrm{~km}$ SE of Long Lake $\left(28^{\circ} 17^{\prime} \mathrm{N}, 96^{\circ} 35^{\prime} \mathrm{W}\right)$.

Tx-1586. Matagorda $B, 15$ to 20

$\mathbf{2 8 3 0} \pm \mathbf{5 0}$

Shell (Donax \& Malinia), depth 4.6 to $6, \mathrm{~N}$ end of Matagorda I. $3.2 \mathrm{~km}$ SE of Air Force Base $\left(28^{\circ} 20^{\prime} \mathrm{N}, 96^{\circ} 25^{\prime} \mathrm{W}\right)$.

Tx-1587. Matagorda JJ, 10 to 15

$5050 \pm 120$

Shell (Donax \& Malinia), depth 3 to $4.6 \mathrm{~m}, \mathrm{~S}$ central portion of Matagorda I. $3.2 \mathrm{~km} \mathrm{NE}$ of Cottonwood Bayou $\left(28^{\circ} 10^{\prime} \mathrm{N}, 96^{\circ} 43^{\prime} \mathrm{W}\right)$. General Comment on Tx-1582-1587 (BHW): these dates record Holocene progradation of Matagorda I. from ca 6000 BP (Wilkinson, 1973). They confirm sea level positions previously reported by others (Scholl \& Stuiver, 1967).

Tx-2129. Matagorda 6, 77

$5300 \pm 90$

Shell, depth $23.5 \mathrm{~m}, 3.2 \mathrm{~km}$ ENE Matagorda Club air field on Matagorda Peninsula $\left(28^{\circ} 28^{\prime} 10^{\prime \prime} \mathrm{N}, 96^{\circ} 16^{\prime} 30^{\prime \prime} \mathrm{W}\right)$.

Tx-2130. Matagorda 13, 20

$930 \pm 60$

Shell, depth $6 \mathrm{~m}, 1.2 \mathrm{~km} \mathrm{~W}$ Hooper Bayou, Matagorda Peninsula $\left(28^{\circ} 36^{\prime} 10^{\prime \prime} \mathrm{N}, 96^{\circ} 01^{\prime} 30^{\prime \prime} \mathrm{W}\right)$.

Tx-2131. Matagorda 33, 25 to 30

$4350 \pm 70$

Shell, depth 7.6 to $9 \mathrm{~m}$, W Spring Bayou Cove, Matagorda Peninsula $\left(28^{\circ} 37^{\prime} 45^{\prime \prime} \mathrm{N}, 95^{\circ} 56^{\prime} 45^{\prime \prime} \mathrm{W}\right)$. 
Tx-2132. Matagorda 34, 20 to 25

$4350 \pm 80$

Shell, depth 13.7 to $15.3 \mathrm{~m}, 1.6 \mathrm{~km}$ ENE Burkhart Cove, Matagorda Peninsula (28 $\left.38^{\prime} 10^{\prime \prime} \mathrm{N}, 95^{\circ} 55^{\prime} 10^{\prime \prime} \mathrm{W}\right)$.

Tx-2133. Matagorda 28, 45 to 50 $6670 \pm 100$

Carbonaceous debris, depth 13.7 to $15.3 \mathrm{~m}$, Brown Cedar cut, Matagorda Peninsula (28 $\left.43^{\prime} 30^{\prime \prime} \mathrm{N}, 95^{\circ} 42^{\prime} 15^{\prime \prime} \mathrm{W}\right)$.

General Comment on Tx-2129-2133 (BHW): samples are from beneath Matagorda Peninsula. They record in sequence estuarine depositional events in Matagorda Bay before deposition of barrier sands.

\section{Brazoria series}

Samples from buried fluvial and deltaic deposits in Holocene Brazos Delta Plain, ca $13 \mathrm{~km}$ NE of Freeport, Brazoria Co, Texas coast $\left(29^{\circ} 02^{\prime}\right.$ $\mathrm{N}, 95^{\circ} 17^{\prime} \mathrm{W}$ ). Coll 1970 by B Cooney and subm by J H McGowen. Nos. in titles indicate depth in $\mathrm{ft}$ below surface.

Tx-1068. Brazoria 12 $3580 \pm 100$ Shell (Rangia), 3.6m depth.

Tx-1069. Brazoria 17 $3590 \pm 70$

Wood, $5.2 \mathrm{~m}$ depth.

Tx-1070. Brazoria 21

$4080 \pm 70$

Freshwater clam, $6.4 \mathrm{~m}$ depth.

General Comment (JHMcG): 1st absolute dates for these deposits, are part of long-term study of sequence of development of coastal zone in Holocene.

\section{San Bernard series}

Washed shell from bay-fill sediments from various locations on Cedar and Cow Trap Lakes, W of mouth of San Bernard R, Brazoria Co, S Texas. Dated to study history of lakes, to enable settlement of legal dispute concerning State or private ownership. Coll 1972 and subm by $\mathrm{J} \mathrm{H}$ McGowen. Nos. in titles refer to depth in $\mathrm{ft}$ below lake bottom.

Tx-1561. Cedar Lakes \#16, 17, 11, 2.5 to $5.0 \quad 670 \pm 130$

Macoma mitchelli, 0.76 to $1.52 \mathrm{~m}$ depth, 5.4 to $5.6 \mathrm{~km} \mathrm{~W}$ of mouth of San Bernard R, 0.48 to $0.8 \mathrm{~km}$ from shoreline $\left(28^{\circ} 50^{\prime} 30^{\prime \prime} \mathrm{N}, 95^{\circ}\right.$ $\left.29^{\prime} \mathrm{W}\right)$.

Tx-1562. Cedar Lakes $19 \& 20,2.5$ to 5.0

$900 \pm 80$

Macoma mitchelli, 0.76 to $1.52 \mathrm{~m}$ depth, $5.4 \mathrm{~km} \mathrm{~W}$ of mouth of San Bernard R, $1.1 \mathrm{~km}$ from shoreline $\left(28^{\circ} 51^{\prime} \mathrm{N}, 95^{\circ} 29^{\prime} \mathrm{W}\right)$.

Tx-1563. Cow Trap Lakes 26, 0 to 3.5, B $310 \pm 90$

Macoma mitchelli, 0 to $1.1 \mathrm{~m}$ depth, ca $182 \mathrm{~m}$ from $\mathrm{N}$ shore of lakes, $8.6 \mathrm{~km} \mathrm{~W}$ of mouth of San Bernard R, $2.4 \mathrm{~km} \mathrm{~N}$ of Intracoastal Canal $\left(28^{\circ} 52^{\prime} \mathrm{N}, 95^{\circ} 31^{\prime} 30^{\prime \prime} \mathrm{W}\right)$. 
Mulinia lateralis, same as Tx-1563, above.

Tx-1565. Cow Trap Lakes 21, 22, 23, 2.5 to $5.0 \quad 510 \pm 80$

Macoma mitchelli, 0.76 to $1.5 \mathrm{~m}$ depth, $6.88 \mathrm{~km} \mathrm{~W}$ of mouth of San Bernard R, 0.3 to $1.4 \mathrm{~km} \mathrm{~N}$ of Intracoastal Canal $\left(28^{\circ} 51^{\prime} 30^{\prime \prime} \mathrm{N}, 95^{\circ} 30^{\prime}\right.$ $\left.44^{\prime \prime} \mathrm{W}\right)$.

Tx-1566. Cedar Lakes 9, 0 to 2

Modern

Brachiodontes sp, 0 to $0.6 \mathrm{~m}$ depth, $45.6 \mathrm{~m}$ offshore, $\mathrm{S}$ shore of Cedar Lakes, $5.3 \mathrm{~km} \mathrm{~W}$ of mouth of San Bernard R, $304 \mathrm{~m}$ from Gulf shoreline $\left(28^{\circ} 50^{\prime} 20^{\prime \prime} \mathrm{N}, 95^{\circ} 29^{\prime} 40^{\prime \prime} \mathrm{W}\right)$.

General Comment (JHMCG): sediment, fauna, and radiocarbon data were used in this study. Fauna indicated lakes always were connected to Gulf. Origin of lakes dated ca $1000 \mathrm{yr}$ вp, much older than age cited by State's opposition in legal case. Dates provided data enabling State to retain possession of this segment of coastal lands.

\section{Other Texas, New Mexico, Tennessee, Florida}

\section{Laubach Cave series, Texas}

Bone from Pleistocene assemblages near 3 sealed entrances in Laubach Cave, $400 \mathrm{~m} \mathrm{~S}$ of SW corner Georgetown city limits, $90 \mathrm{~m} \mathrm{~W}$ of Interstate Hwy 35, Williamson Co, Texas ( $\left.30^{\circ} 37^{\prime} \mathrm{N}, 97^{\circ} 42^{\prime} \mathrm{W}\right)$. Assemblages are not identical, but no stratigraphic or faunal data are available for ascertaining relative ages. Subm by E L Lundelius, Jr, Dept Geol Sci, Univ Texas, Austin.

Tx-1137. Laubach 1, 40673

$15,850 \pm 500$

From Bone Sink \# 1. Coll 1969 by Lundelius.

Tx-1138. Laubach 2, $40722 \quad 13,970 \pm 310$

From surface of steep debris cone and from basin at base. Coll 1966 by Lundelius.

Tx-1139. Laubach 3, 41343

$23,230 \pm 490$

From brown silt at surface of passageway at end of left hand trail. Coll 1966 by Lundelius.

\section{Tx-1419. Laubach 3, 41343}

$28,340 \pm 1710$

From upper fill (red-brown silt) at end of left hand passage, Lunar Landscape Room. Coll 1971 by Billy Davidson.

General Comment (ELL,Jr): dates apply to several extinct and out-ofrange extant taxa in Texas, and demonstrate that cave system had long complex history involving several openings to cave (Lundelius \& Davidson, 1975).

\section{Khulo series, New Mexico}

Samples from Grid Sq IIIB and IIIC, Khulo site (MALB 21), volcanic pit $80 \mathrm{~km} \mathrm{NW}$ of El Paso in Afton Lava flows, Dona Ana Co, New 
Mexico $\left(32^{\circ} 04^{\prime} \mathrm{N}, 107^{\circ} 03^{\prime} \mathrm{W}\right)$; subm to establish dates for microtine distributions and reconstruct past conditions in Rio Grande valley of New Mexico and Texas. Coll 1970 by R A Smartt and subm by A H Harris, Mus of Arid Land Biol, Univ Texas, El Paso.

Tx-2020. Khulo, IIIB, Level 4, wood

$$
2250 \pm 60
$$

Tx-2021. Khulo, IIIB, Level 5, wood

$$
2600 \pm 110
$$

Tx-1558. Khulo, IIIB, Level 8, dung

$$
11,690 \pm 170
$$

Tx-2016. Khulo, IIIC, Level 3, wood

$$
\begin{array}{r}
3630 \pm 80 \\
1370 \pm 60 \\
1700 \pm 70 \\
1790 \pm 190 \\
1550 \pm 60
\end{array}
$$

Tx-2017. Khulo, IIIC, Level 4, wood

Tx-1557. Khulo, IIIC, Level 5, wood

Tx-2018. Khulo, IIIC, Level 6, wood

Tx-1556A. Khulo, IIIC, Levels $6 \& 7$, wood

Tx-1556B. Khulo, IIIC, Levels $6 \& 7$, charcoal

$8210 \pm 220$

Tx-2019. Khulo, IIIC, Level 7, wood

$6710 \pm 160$

General Comment (AHH): dates indicate unexpectedly great disturbance; thus, caution is indicated in interpreting similar dry cave sites in American SW. Dates also affirm Holocene age of Microtus pennsylvanicus (from Level 7 through Level 3, main concentration in Level 6) in Rio Grande valley of S New Mexico. Fauna from all levels is otherwise similar to present fauna of area.

\section{Dry Cave series, New Mexico}

Bone from Dry Cave site, McKittrick Hill, ca $22.5 \mathrm{~km}$ W of Carlsbad, Eddy Co, New Mexico ( $32^{\circ} 22^{\prime} 25^{\prime \prime} \mathrm{N}, 104^{\circ} 28^{\prime} 55^{\prime \prime} \mathrm{W}$ ); dated as part of study of late Pleistocene climatic variation, biotic sequence, and rate of evolution. Coll 1966-1973 and subm by A H Harris.

\section{Tx-1774. Dry Cave, MALB Loc $1 \quad \mathbf{2 9 , 2 9 0} \pm 1060$}

Under Lost Valley Fissure; assoc with cave fissure fill containing fossil vertebrates indicating interstadial conditions.

Tx-1775. Dry Cave, MALB Loc 5

$25,160 \pm 1730$

Waterlain silts in Sabertooth-Camel Maze downslope from Lost Valley Fissure and Room of Vanishing Floor Fissure on intermediate level of cave. Fauna indicates probable interstadial conditions.

Tx-1773. Dry Cave, MALB Loc $26 \& 27$

$\mathbf{3 3 , 5 9 0} \pm \mathbf{1 5 5 0}$

Two samples combined from cave fissure fill in and above Room of Vanishing Floor; Loc 27 stratigraphically higher in same fissure as Loc 26. Faunal remains from both locations indicate similar interstadial conditions. 
General Comment (AHH): dates confirm estimate of interstadial age and approx synchrony for these sites, and rule out possibility of early Wisconsin interstadial age.

\section{Dunmore series, Tennessee}

Samples from Dunmore Site $1,2 \mathrm{~km} \mathrm{E}$ of Greenville, $90 \mathrm{~m} \mathrm{~N}$ of US Hwy $11 \mathrm{E}$ in Greene Co, Tennessee (82 $\left.50^{\prime} \mathrm{N}, 36^{\circ} 10^{\prime} \mathrm{W}\right)$. Coll 1972 and subm by R M Perhac, Dept Geol, Univ Tennessee, Knoxville.

Tx-1620. Dunmore 1, ORDKD1-BJM1

Organic extract from unweathered Ordovician carbonate rock $350 \mathrm{~cm}$ below soil surface, $30 \mathrm{~cm}$ below rock surface.

Tx-1621. Dunmore 1, ORDKD1-BJM2 16,400 \pm 410

Carbonate rock residue (soil) from zone adjacent to rock 316 to $318 \mathrm{~cm}$ below soil surface.

Tx-1622. Dunmore 1, ORDKD1-BJM3 $\quad 12,490 \pm 290$

Carbonate rock residue (soil) from zone adjacent to rock ca 259 to $264 \mathrm{~cm}$ below soil surface.

Tx-1623. Dunmore 1, ORDKD1-BJM4 $\quad \delta^{14} \mathrm{C}=+\mathbf{7 5 . 2 8} \pm \mathbf{4 . 6} \%$

Surface horizon of soil developed from carbonate rock residues.

General Comment (RMP): samples were part of preliminary study of sources and age of organic matter in zone of organic enrichment near carbonate rocks in soils. Dates indicate present surface horizons are not source of much of organic material in enriched zone. Relatively recent age of Tex-1620 is especially surprising.

\section{Key Largo Dry Rocks series, Florida}

Coral samples from reef flat, $1 \mathrm{~m}$ depth, at wreck site on Key Largo Dry Rocks reef, S Florida $\left(25^{\circ} 15^{\prime} \mathrm{N}, 80^{\circ} 18^{\prime} \mathrm{W}\right)$. Coll 1974 and subm by Philip Dustan, Harbor Branch Foundation, Fort Pierce, Florida.

Tx-2134A. M-66, center Acropora palmata.

Tx-2134B. M-66, foot

Same as Tx-2134A, above.

Tx-2135. M-22

$$
\delta^{14} \mathbf{C}=+\mathbf{6 8 . 6 8} \pm \mathbf{4 . 8} \%
$$

Montastrea annularis.

Tx-2136. M-0

Acropora palmata.

$$
\delta^{14} \mathrm{C}=+\mathbf{1 7 7 . 6 6} \pm \mathbf{4 . 1} \%
$$$$
\delta^{14} \mathbf{C}=+\mathbf{8 9 . 6 4} \pm \mathbf{2 . 9} \% \text { o }
$$

$\delta^{14} \mathrm{C}=+\mathbf{2 0 3 . 6} \pm \mathbf{3 . 4} \%$ o

General Comment (PD): samples from centers of largest corals damaged by wreck. All are $<25$ yr. Repair of reef will be rapid. 


\section{Caribbean}

\section{Tx-1896. Chalet Caribe Reef Blast \# 1, Jamaica}

$$
\delta^{14} \mathbf{C}=+\mathbf{4 3 . 5} \pm \mathbf{5 . 7} \% \text { o }
$$

Acropora cervicornus stick coral from $1.2 \mathrm{~m}$ within coral reef at $13 \mathrm{~m}$ depth, ca $7 \mathrm{~m}$ towards shore from drop-off, $100 \mathrm{~m} \mathrm{E}$ of Anchor Canyon, in front of Chalet Carib Hotel, ca $8 \mathrm{~km} \mathrm{~W}$ of Montego Bay, Jamaica, West Indies $\left(18^{\circ} 27^{\prime} \mathrm{N}, 77^{\circ} 58^{\prime} \mathrm{W}\right)$. Coll 1973 by Philip Dustan and Judy Land and subm by Dustan, Harbor Branch Foundation, Fort Pierce, Florida. Comment (JL): date suggests rate of upward reef growth for an "open framework" coral reef is much more rapid than for most Jamaican reefs.

\section{Discovery Bay Nekton Dive Series I, Jamaica}

Samples coll during Nekton submersible dives in Discovery Bay, Jamaica, West Indies (Moore et al, 1976). Coll 1972 and subm by L S Land, Dept Geol Sci, Univ Texas, Austin, Texas. Depths are below mean sea level. Comments by Land.

Tx-1646. Discovery Bay N248D $200 \pm 60$

Sample of sclerosponge covered with recent lithified sediment from $96 \mathrm{~m}$ depth on wall of blast site just E of diving buoy $\left(18^{\circ} 28^{\prime} 30^{\prime \prime} \mathrm{N}\right.$, $\left.77^{\circ} 25^{\prime} 24^{\prime \prime} \mathrm{W}\right)$. Comment: modern age demonstrates that reef framework is constructed by sclerosponges, and lithified at this depth. Rate of sclerosponge growth and wall accretion is clearly significant, but an absolute rate is not possible to assess.

\section{Tx-1647. Discovery Bay N181M}

$8600 \pm 120$

Sample of lithified rock at base of Holocene reef (Dancing Lady Reef) escarpment, $128 \mathrm{~m}$ depth $\left(18^{\circ} 28^{\prime} 30^{\prime \prime} \mathrm{N}, 77^{\circ} 25^{\prime} 30^{\prime \prime} \mathrm{W}\right)$. Comment: base of lithified wall is not a Pleistocene relict, but modern accretion and lithification appears to be very slow.

Tx-1648. Discovery Bay N202

$11,910 \pm 130$

Sample of lithified talus sediment from $180 \mathrm{~m}$ depth from crack in talus slope, E of diving buoy $\left(18^{\circ} 28^{\prime} 36^{\prime \prime} \mathrm{N}, 77^{\circ} 25^{\prime} 18^{\prime \prime} \mathrm{W}\right)$. Comment: sediment is old and lithification is slow at this depth. May represent processes active during late-glacial rise of sea level, and "shut-off" when thermocline trangressed this depth.

Tx-1649. Discovery Bay N232H

$9490 \pm 150$

Sample of probable lithified Holocene talus from transplant cliff blast site, $168 \mathrm{~m}$ depth, just $\mathrm{W}$ of diving buoy $\left(18^{\circ} 28^{\prime} 30^{\prime \prime} \mathrm{N}, 77^{\circ} 25^{\prime}\right.$ $30^{\prime \prime}$ W). Comment: see Tx-1648, above.

\section{Tx-1650. Discovery Bay N244E}

$12,430 \pm 190$

Sample from outcrop equivalent to lithified talus from talus slope, $277 \mathrm{~m}$ depth, just above "Matterhorn", $\mathrm{N}$ of diving buoy (18 $28^{\circ} 36^{\prime \prime} \mathrm{N}$, $\left.77^{\circ} 25^{\prime} 30^{\prime \prime} \mathrm{W}\right)$. Comment: see Tx-1648, above. 


\section{Discovery Bay Nekton Dive Series II, Jamaica}

$(\mathrm{Ca}, \mathrm{Mg}) \mathrm{CO}_{3}$ from Haystacks \#4, Discovery Bay I. slope $\mathrm{N}$ of Discovery Bay diving bouy, Jamaica, West Indies (18 $28^{\prime} 30^{\prime \prime} \mathrm{N}, 77^{\circ} 24^{\prime} 36^{\prime \prime}$ W). Subm to establish rate of sedimentation for Jamaican Is. slope on which no modern (post-5000 yr) lithified sediments have been found. Previous dates include Tx-1647-1650 from lithified sediments below present samples. Coll 1972 by Land, Davies, and Hasting from DSRV (submersible) Nekton "Gamma" and subm 1974 by L S Land. Depth in ft follows Nekton dive no. in titles.

Tx-2014. Discovery Bay, Nekton 192, $400 \quad 910 \pm 60$ $122 \mathrm{~m}$ depth.

Tx-2013. Discovery Bay, Nekton 192, $510 \quad 1030 \pm 60$ $155 \mathrm{~m}$ depth.

Tx-2011. Discovery Bay, Nekton 180, $680 \quad 1360 \pm 80$ $207 \mathrm{~m}$ depth.

Tx-2010. Discovery Bay, Nekton $180,810 \quad 1630 \pm 70$ $246 \mathrm{~m}$ depth.

Tx-2012. Discovery Bay, Nekton 180, $960 \quad 1790 \pm 70$ 292m depth.

Tx-2015. Discovery Bay, Nekton 192, $1010 \quad 3530 \pm 230$ $307 \mathrm{~m}$ depth.

\section{Eastward Station series, Jamaica}

Core samples of impure pelagic carbonate sediment taken from $\mathrm{R} / \mathrm{V}$ "Eastward" N of Jamaica, West Indies. Dated to determine modern sedimentation rates on $\mathrm{N}$ Jamaican island slope and to assess rate of contribution from fringing reefs. Previous dates include Tx-1300 and -1301 (R, 1975, v 17, p 69). Coll 1973 and subm by L S Land. In sample descriptions, "bswi" = below sediment-water interface.

Tx-1825. Eastward Sta 19463 bswi.

Core $412\left(18^{\circ} 48^{\prime} 24^{\prime \prime} \mathrm{N}, 77^{\circ} 23^{\prime} 54^{\prime \prime} \mathrm{W}\right), 5225 \mathrm{~m}$ depth, 55 to $60 \mathrm{~cm}$

Tx-1826. Eastward Sta 19458

$$
27,960 \pm 690
$$

Core $410\left(18^{\circ} 43^{\prime} \mathrm{N}, 77^{\circ} 02^{\prime} \mathrm{W}\right), 4200 \mathrm{~m}$ depth, 59 to $65 \mathrm{~cm}$ bswi.

Tx-1827. Eastward Sta 19464

$9830 \pm 140$ bswi.

Core $413\left(18^{\circ} 40^{\prime} 48^{\prime \prime} \mathrm{N}, 77^{\circ} 03^{\prime} 48^{\prime \prime} \mathrm{W}\right), 4230 \mathrm{~m}$ depth, 35 to $53 \mathrm{~cm}$

Tx-1828. Eastward Sta 21624

$19,720 \pm 250$ bswi.

Core $503\left(19^{\circ} 12^{\prime} 30^{\prime \prime} \mathrm{N}, 77^{\circ} 20^{\prime} 30^{\prime \prime} \mathrm{W}\right), 5100 \mathrm{~m}$ depth, 37 to $42 \mathrm{~cm}$ 
Tx-1829. Eastward Sta 21621

$27,140 \pm 700$

Core $500\left(19^{\circ} 23^{\prime} \mathrm{N}, 77^{\circ} 36^{\prime} \mathrm{W}\right), 5300 \mathrm{~m}$ depth, 56 to $61 \mathrm{~cm}$ bswi.

General Comment (LSL): sedimentation rates range from $<13$ to $45 \mathrm{~mm} /$ $1000 \mathrm{yr}$, and appear to be relatively normal abyssal sedimentation rates. Surprisingly little reef sediment is derived from Jamaica. Sediments, $900 \mathrm{~m}$ thick, in abyssal basins of Cayman Trench suggest an age of opening ca 45 million yr (L S Land, $\mathrm{ms}$, in preparation).

Tx-2185. Eastward Sta 16283

$36,020 \pm 2320$

Core $289\left(18^{\circ} 35^{\prime} \mathrm{N}, 77^{\circ} 23^{\prime} 42^{\prime \prime} \mathrm{W}\right)$, $2600 \mathrm{~m}$ depth, half of sample $47 \mathrm{~cm}$ bswi, remainder $61 \mathrm{~cm}$ bswi.

Tx-2186. Eastward Sta 16285

$41,820 \pm 6830$

Core $290\left(18^{\circ} 33^{\prime} 30^{\prime \prime} \mathrm{N}, 77^{\circ} 24^{\prime} 18^{\prime \prime} \mathrm{W}\right)$, $2135 \mathrm{~m}$ depth, $1 / 5$ of sample from each of following depths bswi: 95, 107, 114 to 118, 122, \& 140 to $143 \mathrm{~cm}$. Comment (LSL): these are 2 actual reef sediment beds, which are clearly not modern. See discussion of Burne (1974) in Moore et al (1976).

\section{Bluehole series, Belize}

Aragonite from different layers of massive submarine cement rind developed on stalactite in sink-hole, at $50 \mathrm{~m}$ depth, from Bluehole, Lighthouse Reef, Belize $\left(17^{\circ} 19^{\prime} \mathrm{N}, 87^{\circ} 33^{\prime} \mathrm{W}\right)$. Stalactite formed during last glacial period. Dates will help establish sequence of events leading to precipitation of this massive aragonite deposit. Coll by $\mathrm{F} R$ Dill and subm by L S Land.

$$
\begin{array}{llr}
\text { Tx-1770. } & \text { Bluehole, skeletal rind } & 2919 \pm 90 \\
\text { Tx-1771. } & \text { Bluehole, inner } 1.5 \mathrm{~cm} & 10,220 \pm 120 \\
\text { Tx-1772. } & \text { Bluehole, outer } 1.5 \mathrm{~cm} & 11,540 \pm 180
\end{array}
$$

General Comment (LSL): massive cementation occurred in short interval during rise of sea level. Ages have been confirmed by U-Th method.

\section{Tx-1752. Puerto Colombia, CH-1, Venezuela $410 \pm 40$}

Coral from $2 \mathrm{~km} \mathrm{~W}$ of Puerto Colombia, Estado Aragua, Venezuela, along trail to Aroa $\left(10^{\circ} 30^{\prime} \mathrm{N}, 67^{\circ} 38^{\prime} \mathrm{W}\right)$. Taken from slabs of coral (too large for introduction by man) overlying metamorphic rocks ca $30 \mathrm{~m}$ above present sea level. Subm to determine late Quaternary rate of uplift of coastal ranges and elevations of past sea levels. Coll 1973 and subm by C Schubert, Inst Venezolano Investigaciones Cientificas, Caracas, Venezuela. Sample divided into 2 parts, prepared and counted separately: $470 \pm 60,350 \pm 60$. Final date is average. Comment (CS\&SVJr): ${ }^{230} \mathrm{Th} /$ ${ }^{238} \mathrm{U}$ analysis dates sample: $1400 \mathrm{BP}$. Petrographic analysis indicates partial recrystallization of the aragonite, explaining younger ${ }^{14} \mathrm{C}$ age. If $\mathrm{Th} / \mathrm{U}$ gives true age, Cordillera of Central coast of Venezuela has uplifted at rate of $1.2 \mathrm{~cm} / \mathrm{yr}$ during last millennium (Schubert et al, 1975). 


\section{Aruba Island series, Dutch Leeward Islands}

Coral coll from top of 2nd terrace of a 3-terrace complex, 5 to $15 \mathrm{~m}$ alt, from sites on Aruba I. (12 $\left.30^{\prime} \mathrm{N}, 70^{\circ} \mathrm{W}\right)$, subm to date Quaternary events in Dutch Leeward Is. which may be correlated with Venezuelan is. Coll 1972 and subm by C Schubert. Samples were split after pretreatment, the 2 parts prepared and counted separately. Date is average, and individual dates are given in sample description.

Tx-1899. Aruba, ARU-1, 2

Guadirikiri site, NE coast. $41,890 \pm 4820,38,780 \pm 2980$.

Tx-1900. Aruba, ARU-6

$25,810 \pm 350$

$\mathrm{E}$ of Ayo locality, NE coast. 26,110 $\pm 680,25,500 \pm 480$.

Tx-1901. Aruba, ARU-7

$32,010 \pm 850$

Loc same as ARU-6 (Tx-1900, above). 32,300 $\pm 1330,31,720 \pm 1050$.

Tx-1902. Aruba, ARU-9

$28,990 \pm 660$

$\mathrm{N}$ of Malmok loc, NW end of i. 29,960 $\pm 990,28,010 \pm 860$.

General Comment (CS\&SVJr): range of ${ }^{14} \mathrm{C}$ ages is consistent with that of La Orchila I. series, below. Petrographic and X-ray analyses revealed significant recrystallization of all Aruba samples, except Tx-1902. ${ }^{14} \mathrm{C}$ ages most probably represent recrystallization age.

\section{La Orchila Island series}

Samples from La Orchila I., off coast of Venezuela, dated for age and origin of terrace and recent beach deposits (Schubert \& Valastro, 1974; 1976). Coll 1972 and subm by C Schubert. Most samples were split after pretreatment, the 2 parts prepared and counted separately: date is average, and individual dates are given in sample description.

\section{Tx-1791. La Orchila, LO-2}

$14,020 \pm 160$

Beach rock, Site $3,5 \mathrm{~km} \mathrm{E}$ of military base $\left(11^{\circ} 48^{\prime} 30^{\prime \prime} \mathrm{N}, 66^{\circ} 08^{\prime}\right.$ $30^{\prime \prime} \mathrm{W}$ ), overlying coral rubble terrace 2 to $3 \mathrm{~m}$ above sea level. $14,280 \pm$ $220,13,750 \pm 240$.

Tx-1742. La Orchila, LO-3

$\mathbf{3 0 , 5 3 0} \pm \mathbf{7 9 0}$

Shell, Site 1, $5 \mathrm{~km} \mathrm{E}$ of military base (11 $48^{\prime} 30^{\prime \prime} \mathrm{N}, 66^{\circ} 08^{\prime} 30^{\prime \prime} \mathrm{W}$ ), $1 \mathrm{~m}$ above salt flat at level of wave-cut notch in hillside.

\section{Lx-1792. La Orchila, LO-5A}

$19,190 \pm 180$

Beach rock with coral fragments, Site $6,4 \mathrm{~km} \mathrm{E}$ of military base $\left(11^{\circ} 47^{\prime} 30^{\prime \prime} \mathrm{N}, 66^{\circ} 09^{\prime} 30^{\prime \prime} \mathrm{W}\right.$ ), overlying terrace consisting of coral and shell fragments, $1.5 \mathrm{~m}$ above salt flat at elev of wave-cut notch. $18,940 \pm$ $240,19,430 \pm 270$.

Tx-1743. La Orchila, LO-5B

Shell (Bulla sp?), Site 6 (see Tx-1792, above).

$18,880 \pm 330$ 
Tx-1793. La Orchila, LO-6

$14,970 \pm 160$

Beach rock with coral fragments, Site $8,1 \mathrm{~km}$ SE of military base $\left(11^{\circ} 48^{\prime} \mathrm{N}, 66^{\circ} 12^{\prime} \mathrm{W}\right)$, overlying 2 to $3 \mathrm{~m}$ terrace. $14,750 \pm 210,15,190 \pm$ 250 .

Tx-1794. La Orchila, LO-7

$3680 \pm 60$

Beach rock, Site 10, $2 \mathrm{~km} \mathrm{SE}$ of military base $\left(11^{\circ} 47^{\prime} \mathrm{N}, 66^{\circ} 11^{\prime} \mathrm{W}\right)$, at sea level within Holocene beach deposits. $3680 \pm 80,3680 \pm 100$.

Tx-1795. La Orchila, LO-8

$8060 \pm 100$

Beach rock, Site $14,3 \mathrm{~km}$ SE of military base $\left(11^{\circ} 46^{\prime} \mathrm{N}, 66^{\circ} 09^{\prime} 30^{\prime \prime}\right.$ $W)$, overlying 2 to $3 \mathrm{~m}$ coral rubble terrace. $8200 \pm 150,7910 \pm 120$.

Tx-1796. La Orchila, LO-9

$17,160 \pm 190$

Coral, Site 14 (see Tx-1795, above). 17,060 \pm 300, 17,260 \pm 240 .

Tx-1744. La Orchila, LO-11

$21,130 \pm 240$

Coral and shell, Site $17,4 \mathrm{~km} \mathrm{SE}$ of military base $\left(11^{\circ} 47^{\prime} \mathrm{N}, 66^{\circ} 09^{\prime}\right.$ $30^{\prime \prime} \mathrm{W}$ ), overlying $0.6 \mathrm{~m}$ coral fragment terrace exposed along $\mathrm{S}$ shore of i. $20,910 \pm 280,21,560 \pm 390$.

Tx-1797. La Orchila, LO-12

$14,970 \pm 160$

Coral, Site $17,6 \mathrm{~km} \mathrm{SE}$ of military base $\left(11^{\circ} 46^{\prime} \mathrm{N}, 66^{\circ} 09^{\prime} \mathrm{W}\right)$, near base of top of 2 to $3 \mathrm{~m}$ terrace. $15,060 \pm 240,14,870 \pm 210$.

Tx-1798. La Orchila, LO-13

$\mathbf{2 5 , 5 3 0} \pm \mathbf{5 2 0}$

Coral, Site $19,6.5 \mathrm{~km} \mathrm{SE}$ of military base $\left(11^{\circ} 46^{\prime} \mathrm{N}, 66^{\circ} 09^{\prime} \mathrm{W}\right)$, near base of top of 2 to $3 \mathrm{~m}$ terrace. $25,600 \pm 580,25,460 \pm 850$.

Tx-1799. La Orchila, LO-14

$\mathbf{2 9 , 3 0 0} \pm \mathbf{7 6 0}$

Coral, Site $21,2 \mathrm{~km} \mathrm{NE}$ of military base $\left(11^{\circ} 48^{\prime} 30^{\prime \prime} \mathrm{N}, 66^{\circ} 11^{\prime} \mathrm{W}\right)$, overlying 2 to $3 \mathrm{~m}$ terrace, overlain by talus deposits of Cerro Walker. $29,010 \pm 1190,29,590 \pm 940$.

Tx-1800. La Orchila, LO-15

$1290 \pm 60$

Beach rock with coral and shell fragments, Site $22,1.5 \mathrm{~km} \mathrm{NE}$ of military base $\left(11^{\circ} 49^{\prime} \mathrm{N}, 66^{\circ} 11^{\prime} \mathrm{W}\right)$, at sea level within wave zone overlying recent beach rock, $\mathrm{N}$ foot of Cerro Walker. $1450 \pm 100,1130 \pm 70$.

Tx-1745. La Orchila, LO-16

$\mathbf{4 1 , 2 8 3} \pm \mathbf{5 0 3 0}$

Coral, Site $23,2 \mathrm{~km} \mathrm{NE}$ of military base $\left(11^{\circ} 49^{\prime} \mathrm{N}, 66^{\circ} 10^{\prime} 30^{\prime \prime} \mathrm{W}\right)$, near top of 2 to $3 \mathrm{~m}$ coral fragment terrace along $\mathrm{S}$ shore of lagoon $\mathrm{E}$ of Cerro Walker. $39,330 \pm 6930,45,190 \pm 7300$.

Tx-1801. La Orchila, LO-17

$15,410 \pm 170$

Coquinoid beach rock, Site $24,2.5 \mathrm{~km}$ E of military base $\left(11^{\circ} 48^{\prime}\right.$ $\left.30^{\prime \prime} \mathrm{N}, 66^{\circ} 10^{\prime} \mathrm{W}\right)$, overlying terrace below wavecut notch in peridotite. $15,520 \pm 250,15,300 \pm 220$. 
Tx-1802. La Orchila, LO-18

Beach rock, Site $27,5 \mathrm{~km}$ NE of military base, left side of rd to El Mangle $\left(11^{\circ} 49^{\prime} \mathrm{N}, 66^{\circ} 09^{\prime} \mathrm{W}\right)$; overlying 2 to $3 \mathrm{~m}$ terrace. $20,780 \pm 370$, $21,020 \pm 300$.

\section{Tx-1746. La Orchila, LO-19}

$27,340 \pm 460$

Coral, Site $30,5 \mathrm{~km}$ NE of military base and $0.8 \mathrm{~km} \mathrm{~W}$ of El Mangle $\left(11^{\circ} 49^{\prime} \mathrm{N}, 66^{\circ} 08^{\prime} \mathrm{W}\right)$; near top of 2 to $3 \mathrm{~m}$ coral fragment terrace exposed along $\mathrm{N}$ shore of $\mathrm{i} .27,210 \pm 640,27,600 \pm 650$.

Tx-1747. La Orchila, LO-20

$\mathbf{2 8 , 2 8 0} \pm \mathbf{5 9 0}$

Shell (Strombus gigas), Site $31,9.5 \mathrm{~km} \mathrm{E} \mathrm{of} \mathrm{military} \mathrm{base}\left(11^{\circ} 49^{\prime}\right.$ $\left.42^{\prime \prime} \mathrm{N}, 66^{\circ} 06^{\prime} 30^{\prime \prime} \mathrm{W}\right)$; near top of 2 to $3 \mathrm{~m}$ coral fragment terrace exposed along NE shore of i. 28,010 $\pm 700,28,810 \pm 950$.

Tx-1748. La Orchila, LO-21

$28,600 \pm 540$

Shell (Strombus gigas), Site $34,8 \mathrm{~km}$ E of military base midway between Cerro del Medio and Cerro Angola (11 $\left.1^{\circ} 49^{\prime} \mathrm{N}, 66^{\circ} 07^{\prime} \mathrm{W}\right)$; near top of 2 to $3 \mathrm{~m}$ terrace, cemented to terrace by carbonate cement. 29,310 $\pm 800,28,250 \pm 720$.

Tx-1803. La Orchila, LO-22

$14,570 \pm 150$

Beach rock, Site $34,10 \mathrm{~km}$ E of military base $\left(11^{\circ} 49^{\prime} 30^{\prime \prime} \mathrm{N}, 66^{\circ} 06^{\prime}\right.$ $\left.30^{\prime \prime} \mathrm{W}\right)$; near top of 2 to $3 \mathrm{~m}$ terrace on beach cliff. $14,930 \pm 240,14,210$ \pm 170 .

Tx-1804. La Orchila, LO-23

$120 \pm 70$

Beach rock, Site $36,10 \mathrm{~km}$ E of military base $\left(11^{\circ} 48^{\prime} 30^{\prime \prime} \mathrm{N}, 66^{\circ} 06^{\prime}\right.$ $\mathrm{W})$; near sea level from beach rock outcropping beneath beach sand.

\section{Tx-1749. La Orchila, LO-24}

$23,520 \pm 270$

Coral, Site $38,10 \mathrm{~km}$ E of military base, $0.5 \mathrm{~km}$ from $\mathrm{E}$ shore of $\mathrm{i}$. $\left(11^{\circ} 48^{\prime} \mathrm{N}, 66^{\circ} 06^{\prime} \mathrm{W}\right)$, near top of 2 to $3 \mathrm{~m}$ coral fragment terrace exposed along $\mathrm{E}$ shore of $\mathrm{i}$. behind storm beach. 23,170 $\pm 320,24,220 \pm 440$.

Tx-1750. La Orchila, LO-25

$\mathbf{9 7 0} \pm \mathbf{5 0}$

Shell (Strombus gigas), Site $39,8.5 \mathrm{~km}$ SE of military base $\left(11^{\circ} 46^{\prime}\right.$ $\left.30^{\prime \prime} \mathrm{N}, 66^{\circ} 07^{\prime} \mathrm{W}\right)$, near top of 2 to $3 \mathrm{~m}$ coral fragment terrace exposed along $\mathrm{W}$ shore of $\mathrm{i}$.

\section{Tx-1751. La Orchila, LO-26}

Beach rock, Site 39. $1860 \pm 80,2100 \pm 70$.

$2020 \pm 50$

General Comment (CS\&SVJr): ages range from 8000 to 41,000 yr BP. X-ray diffraction and petrographic data indicate alteration and recrystallization of original aragonite, at least in part, rendering ${ }^{14} \mathrm{C}$ ages too young; dates are, at best, ages of recrystallization. Two ${ }^{230} \mathrm{Th} /{ }^{238} \mathrm{U}$ dates on coral: ca $131,000 \mathrm{yr}$. If Th/U date is true age, terrace is probably of Sangamon age. 
Gran Roque Island series, Los Roques Archipelago, Venezuela

Shell (Strombus) from $0.5 \mathrm{~km} \mathrm{~W}$ of Gran Roque, $\mathrm{S}$ shore of Gran Roque I. $\left(11^{\circ} 57^{\prime} \mathrm{N}, 66^{\circ} 40^{\prime} \mathrm{W}\right)$, subm to date terrace at +1 to $2 \mathrm{~m}$ for correlation with similar terrace on La Orchila I. Coll 1972 and subm by G Schubert.

Tx-1897. Gran Roque, GR-1

$29,310 \pm 1000$

From E side of promontory.

Tx-1898. Gran Roque, GR-2

$\mathbf{3 0 , 0 0 0} \pm \mathbf{8 1 0}$

From W side of promontory. 29,960 $\pm 990,30,030 \pm 1270$.

General Comment (CS\&SVJr): X-ray diffraction indicates that samples consist of aragonite and that their ${ }^{14} \mathrm{C}$ age agrees with age of similar shells from similar geol setting on La Orchila I. (see La Orchila I. series, above).

\section{Nullarbor Plain, Australia}

Bone and charcoal from now-absent or extinct faunal assemblages on Nullarbor Plain, S central Australia, in states of W and S Australia. Samples date fauna with now disjunct distributions on either side of plain. Dates should also be relevant to problem of extinction of large marsupials in Australia. Coll 1964 by E L Lundelius, Jr, and W D Turnbull, and subm by Lundelius, Dept Geol Sci, Univ Texas, Austin.

Tx-1153. Wombat Cave, S Australia

$19,240 \pm 400$

Bone from 91 to $107 \mathrm{~cm}$ below surface in Wombat Cave (TMM 41374 ), ca $42 \mathrm{~km} \mathrm{~W}$ of Koonalola and $0.8 \mathrm{~km} \mathrm{~S} 32^{\circ} \mathrm{W}$ from shed tanks on Fyre Hwy $\left(31^{\circ} 03^{\prime} \mathrm{S}, 127^{\circ} 0^{\prime} \mathrm{E}\right)$. Comment (ELL,Jr): date is only current evidence for Pleistocene age of this deposit.

\section{Madura Cave series, Western Australia}

Bone from late Pleistocene and Holocene fauna in Madura Cave, ca $14.5 \mathrm{~km} \mathrm{~S}$ of Madura $\left(32^{\circ} 02^{\prime} \mathrm{S}, 127^{\circ} 00^{\prime} \mathrm{E}\right)$, W Australia.

Tx-1140. Madura Cave 652

$18,990 \pm 220$

Pit 4, top $15 \mathrm{~cm}$ of Unit 2.

Tx-1141. Madura Cave 653

$20,000 \pm 430$

Pit 4, middle $15 \mathrm{~cm}$ of Unit 2.

Tx-1142. Madura Cave 654

$22,400 \pm 580$

Pit 3, base of Unit 2, above collapse.

Tx-1143. Madura Cave 655

$37,880 \pm 3520$

Pit 4, base of Unit 7 .

Tx-1144. Madura Cave 656

$22,220 \pm 570$

Pit 4, between Units 4 and 5 . 
Tx-1145. Madura Cave 657

Pit 3, Unit 2.

Tx-1146. Madura Cave 658

Top $30 \mathrm{~cm}$ of Unit 1.

General Comment (ELL,Jr): dates confirm late Pleistocene and early Holocene age of this faunal sequence (Lundelius \& Turnbull, 1973).

Webb's Cave series, Western Australia

Holocene assoc in N alcove of Webb's Cave (TMM 41209), $9.7 \mathrm{~km} \mathrm{~N}$ of Mundrabilla Sta Homestead, $80 \mathrm{~km}$ E of Madura $\left(31^{\circ} 48^{\prime} \mathrm{S}, 127^{\circ} 56^{\prime} \mathrm{E}\right)$.

Tx-1147. Webb's Cave 906

$5030 \pm 90$

Bone, 2.5 to $7.5 \mathrm{~cm}$ below surface.

Tx-1148. Webb's Cave 907

Charcoal, 2.5 to $7.5 \mathrm{~cm}$ below surface.

$1500 \pm 70$

Tx-1149. Webb's Cave 908

$5690 \pm 80$

Charcoal, 7.5 to $15 \mathrm{~cm}$ below surface.

Tx-1150. Webb's Cave 909

Bone, 7.5 to $15 \mathrm{~cm}$ below surface.

$7950 \pm 130$

Tx-1151. Webb's Cave 910

$11,420 \pm 630$

Bone, 15 to $22.5 \mathrm{~cm}$ below surface.

Tx-1152. Webb's Cave 911

Bone, 22.5 to $30 \mathrm{~cm}$ below surface.

$11,970 \pm 200$

General Comment (ELL,Jr): dates indicate terminal Pleistocene and early Holocene age for faunal sequence.

\section{Other Australia}

\section{Bone Cave series, New South Wales}

Marsupial bone from Bone Cave, $8 \mathrm{~km} \mathrm{~S}$ of Wellington, New South Wales, Australia $\left(32^{\circ} 30^{\prime} \mathrm{S}, 149^{\circ} 00^{\prime} \mathrm{E}\right)$. From Loc 3 (Frank, 1971, p 16, 25). Coll 1967 by R M Frank and subm by E L Lundelius, Jr.

Tx-672. Bone Cave floor

$$
22,570 \pm 610
$$

From Unit 3 (RB), loose material on floor.

Tx-673. Bone Cave, lower

From base of Unit 3 (RB).

General Comment (ELL,Jr): dates apply to 1 of longest-known and most diverse Pleistocene fauna in Australia.

II. ARGHAEOLOGIC SAMPLES

Alfred Mackin series

$$
\text { Texas }
$$

Charcoal from Alfred Mackin site (41 LR 36; Mallouf, 1976, p 65-303; discussion, p 448), early Caddo village and mound site on Nolan 
Creek, 24km NE of Paris, Lamar Co, NE Texas (33 $47^{\prime} 53^{\prime \prime}$ N, $95^{\circ} 20^{\prime}$ 24" W). Coll 1974 \& 1975 and subm by R J Mallouf, Texas Hist Comm, Austin, Texas.

Tx-2167. Alfred Mackin \#8

$\mathbf{7 1 0} \pm 40$

Mound B, N259/E462, Feature VIIb, Level 1, $15 \mathrm{~cm}$ depth; midden area within burned house; Early Caddoan, Gibson aspect.

Tx-2170. Alfred Mackin \#31

$1320 \pm 170$

Mound B, N259/E462, Feature VIIc, Postmold \# 1; should date burning of house; probably pre-Caddoan, Early Ceramic.

\section{Tx-2171. Alfred Mackin \#32}

$890 \pm 60$

Mound A, Trench 1, Units 2 \& 3 at contact between Zones A-4 and A-8; subm to establish length of time between phases of mound construction.

Tx-2172. Alfred Mackin \#39

$1000 \pm 70$

Mound A, Trench 1, Unit 2, Zone A-8, 100.48m alt; major construction phase of mound.

Tx-2173. Alfred Mackin \#4.1

$740 \pm 340$

Mound A, Trench 1, Unit 6, Zone A-3, 99.39m alt; premound humus zone, thought to be pre-Caddoan, Early Ceramic.

Tx-2174. Alfred Mackin \#44

$1100 \pm 70$

Mound A, Trench 1, Unit 2, Feature I, Component 5, 99.81m alt; premound occupation, Early Caddoan.

Tx-2175. Alfred Mackin \#47

$940 \pm 40$

Mound A, Trench 1, Unit 2, below Component 6 of Feature I, $99.59 \mathrm{~m}$ alt; premound surface; Early Caddoan.

Tx-2176. Alfred Mackin \#48

$970 \pm 40$

Mound A, Trench 1, Unit 2, uppermost log of Feature I, $99.83 \mathrm{~m}$ alt; premound occupation; Early Caddoan.

Tx-2177. Alfred Mackin \#34, 47

Mound A, Trench 1, Unit 4, Feature IIIa hearth; major mound construction phase; Early Caddoan.

Tx-2178. Alfred Mackin \#24, 29

$1410 \pm 150$

Mound B, N255/E463, Zone B-4, top of buried A-horizon, 99.38 to 99.44m alt; premound occupation; pre-Caddoan, Early Ceramic.

Tx-2179. Alfred Mackin \#35, 48

$1010 \pm 80$

Mound A, Trench 1, Unit 4, Component D-6, Feature IIIe, $100.45 \mathrm{~m}$ alt; major mound construction phase; Early Caddoan.

General Comment (RJM): except for Tx-2173, which is anomalously late, dates support archaeol sequence: Tx-2170, -2173, -2178, pre-Caddoan; 
Tx-2172, -2174 -2177, -2179, Early Caddoan; Tx-2167, later Early Caddoan occupation of mound after burning of house.

Tx-1511. Millican Bench site

Charcoal from S175.10/E151.25, base of Level 3, Millican Bench site (41 TV 163), Transitional Archaic site at NW limits of Austin, Texas, on tributary of Bull Creek ( $\left.30^{\circ} 22^{\prime} 57^{\prime \prime} \mathrm{N}, 97^{\circ} 44^{\prime} 59^{\prime \prime} \mathrm{W}\right)$. Coll and subm 1971 by F A Weir, Texas Hwy Dept, Austin, Texas. Comment (FAW): date significantly later than expected for Transitional Archaic site; latest occupation of site thought to be ca AD 1200. Reason for discrepancy not known.

\section{Loeve-Fox Series II, Texas}

Charcoal from Loeve-Fox site (41 WM 230; Prewitt, 1974; these and related dates discussed p 22-30), left bank San Gabriel R, 8km NNE of Taylor, Williamson Co, Texas, in Laneport Reservoir basin $\left(30^{\circ} 39^{\prime} 25^{\prime \prime}\right.$ N, $97^{\circ} 24^{\prime} 58^{\prime \prime}$ W). Coll 1972-73 and subm by E R Prewitt, Texas Archeol Survey, Univ Texas, Austin. For previous dates, see R, 1975, v 17, p 83. Hyphenated nos. in titles refer to depth in $\mathrm{ft}$.

Tx-1925. Loeve-Fox 20, 2.5-3

$870 \pm 60$

F-1c burial pit, N1000/W1030, 76 to $91 \mathrm{~cm}$ depth. Assoc with Scallorn arrow points.

Tx-1923. Loeve-Fox 33 and 56, 3-3.5

$$
940 \pm 60
$$

F-lc burial pit, 91 to $106 \mathrm{~cm}$ depth.

Tx-1927. Loeve-Fox 6 and 10, 2.5-3 $1480 \pm 80$

F-2 hearth in pit, N1060/W990, 76 to $91 \mathrm{~cm}$ depth. Assoc with Darl projectile points.

Tx-1924. Loeve-Fox 47 to $48,3 \quad 2100 \pm 880$

F-5 hearth in pit, N895/W1000, 91cm depth. Assoc with Ensor projectile points.

Tx-1922. Loeve-Fox 44, 3.5

$1670 \pm 100$

Same as Tx-1924, above; $106 \mathrm{~cm}$ depth.

Tx-1926. Loeve-Fox 26, 4-4.5 $1300 \pm 60$

F-11 hearth and ash pit, N895/W990, 120 to $137 \mathrm{~cm}$ depth. Assoc with Ensor projectile points.

Tx-1764. Loeve-Fox 13a, 1.5-2

$1080 \pm 60$

F-4 (Hearth 2), N895/W990, 45 to $60 \mathrm{~cm}$ depth.

General Comment (ERP): Tx-1925 and -1923 date Austin phase cemetery beginning ca AD 1000. Tx-1764 confirms assoc of Hearth 2 with Austin phase occupation. Other dates establish AD 200-700 as approx range of Twin Sisters phase in San Gabriel R valley. 


\section{Chupik Site series, Texas}

Wood and hackberry seed charcoal from Chupik site (41 ML 44), $19.2 \mathrm{~km} \mathrm{NW}$ of Waco, Texas, $2.1 \mathrm{~km} \mathrm{NW}$ of confluence of Brazos R and Aquilla Creek $\left(31^{\circ} 41^{\prime} 10^{\prime \prime} \mathrm{N}, 97^{\circ} 10^{\prime} 30^{\prime \prime} \mathrm{W}\right)$. Pottery shows relationships with George C. Davis site and other E Texas sites; other artifacts are characteristic of Central Texas aspect. Coll 1972 by D A Story and subm by C E Locke, Texas Archeol Research Lab, Balcones Research Center, Univ Texas, Austin.

\section{Tx-1753. Chupik, Zone II}

Wood charcoal, fill, N936/W948, 99.12m.

\section{Tx-1756. Chupik, F-1-4}

Wood and hackberry seed charcoal, N936/W947.5, top of Zone II. General Comment (CEL): large error in dates due to small sample size; however, dates are fairly consistent, fall within time range expected on basis of artifact assemblages, and coincide with period during which Davis site in E Texas was experiencing internal changes.

\section{Tx-2309. 41 KE 49/N-2}

$1120 \pm 60$

Charcoal from Site $41 \mathrm{KE} 49$ on Cibolo Creek, S of Upper Cibolo $\mathrm{Rd}, 8 \mathrm{~km} \mathrm{NW}$ of Boerne, Kendall Co, Texas $\left(29^{\circ} 49^{\prime} 30^{\prime \prime} \mathrm{N}, 98^{\circ} 47^{\prime} \mathrm{W}\right)$. From beneath hearth, Unit N, Level 2, 35cm depth; assoc with La Jita and Bulverde points. Coll 1975 by T C Kelly and subm by T R Hester, Center for Archaeol Research, Univ Texas at San Antonio. Comment (TRH): given assoc Early Archaic point types, date should be much earlier ( $c f$ Hester, 1971, re La Jita type). Charcoal perhaps intrusive via rodent burrowing into hearth area.

\section{Tx-2207. Hinojosa site}

$\mathbf{5 8 0} \pm \mathbf{5 0}$

Charcoal from Hinojosa site (41 JW 8), W bank of Chiltipin Creek, $14 \mathrm{~km}$ NW of Alice, Jim Wells Co, S Texas $\left(27^{\circ} 53^{\prime} \mathrm{N}, 98^{\circ} 07^{\prime} 15^{\prime \prime} \mathrm{W}\right)$. From Unit S20/W3, Level 1, 0 to $15 \mathrm{~cm}$ depth; assoc with late prehistoric occupation represented by Perdiz points, bone-tempered pottery, small end scrapers, Bison and other fauna. Coll 1975 by F A Bass, Jr and subm by T R Hester. Comment (TRH): date agrees with others from S Texas late prehistoric sites (Hill \& Hester, 1973; Hester \& Hill, 1975). Probably a good indication of age of late prehistoric tradition in parts of $S$ Texas (with traits as described above) described in Hester (1975).

\section{Tortuga Flat series, Texas}

Charcoal from Tortuga Flat site (41 ZV 155), E floodplain Tortugas Creek, $13 \mathrm{~km}$ E of Crystal City, Zavala Co, Texas $\left(28^{\circ} 45^{\prime} 30^{\prime \prime} \mathrm{N}, 99^{\circ} 45^{\prime}\right.$ $30^{\prime \prime} \mathrm{W}$ ). Protohistoric occupation, bone-tempered ceramics, varied arrowpoint forms, rich fauna. Coll 1971 by T C Hill, Jr; subm by Hill and T R Hester. Comments by TCH \& TRH. 
Tx-1514. Tortuga Flat, 1

From Test Pit 1, Level 1, 0 to 6 in (0 to $15 \mathrm{~cm}$ ) below surface. Comment: assoc with lozenge-shaped arrow point, faunal remains. Date somewhat late, possibly caused by mixing of charcoal from occupation zone with post-occupational deposits.

Tx-1515. Tortuga Flat, 2

From "Bone Pile", accumulation of varied faunal and occupational debris, including triangular arrow points. Comment: date is reasonable for protohistoric occupation. Assoc fauna includes antelope and bison, recorded by early Spanish explorers in region but absent in last 200 to $300 \mathrm{yr}$.

General Comment: absence of evidence of Spanish contact makes Tx-1514 seem late but still possible. In general, dates, especially Tx-1515, corroborate stylistic evidence for protohistoric time. At nearby Site $41 \mathrm{ZV}$ 14, latest ceramic assemblage has ${ }^{14} \mathrm{C}$ date of $<300$ (UCLA 1821A: Hester \& Hill, 1972, p 38, footnote).

\section{Chaparrosa Ranch series, Texas}

Charcoal from sites on Turkey Creek, on Chaparrosa Ranch, NW Zavala Co, near La Pryor, Texas. Coll and subm 1970 by T R Hester.

\section{Tx-1525. Chaparrosa 14}

$1180 \pm 120$

From Test Pit 2, Level 2, 20 to $40 \mathrm{~cm}$ below surface, at Chaparrosa 14 (41 ZV 11), W floodplain Turkey Creek, $15 \mathrm{~km} \mathrm{SW}$ of La Pryor $\left(28^{\circ}\right.$ $\left.51^{\prime} \mathrm{N}, 99^{\circ} 58^{\prime} \mathrm{W}\right)$. Comment (TRH): date within predicted time span of AD 500 to 1000; represents occupation near middle of depositional sequence at site. Another sample from same pit and level is UCLA-1821C, $1535 \pm 100$ (Hester, pers commun). No diagnostic artifacts in this level. Higher, in Level 1, were small side-notched points and UCLA-1821B, $<300$ (Hester, pers commun).

\section{Tx-1526. Chaparrosa 28}

$430 \pm 60$

From Test Pit 2, Level 3, 50cm below surface, at Chaparrosa 28 (41 ZV 83), E bank main channel Turkey Creek, ca $13 \mathrm{~km} \mathrm{SW}$ of La Pryor $\left(28^{\circ} 53^{\prime} \mathrm{N}, 99^{\circ} 57^{\prime} \mathrm{W}\right)$. Assoc with concave-base lanceolate fragment of point or knife. Comment (TRH): date reasonably agrees with UCLA-1821D, <300, from same level (Hester, per commun). Apparently, $50 \mathrm{~cm}$ alluvium accumulated here in past 300 to $400 \mathrm{yr}$. Dates indicate that later occupation, Level 1, with stemmed arrowpoints and triangular convex-based arrowpoints, must be within early historic era, although no European artifacts have been found. From deeper level, 4, came UCLA 1821E, $1400 \pm 100$ (Hester, pers commun).

\section{Tx-1527. Chaparrosa 27}

$\mathbf{5 0 0} \pm \mathbf{7 0}$

From Test Pit 1, Level 3, 40 to $60 \mathrm{~cm}$ below surface, at Chaparrosa 27 (41 ZV 82), W floodplain Turkey Creek, ca $20 \mathrm{~km} \mathrm{SW}$ of La Pryor $\left(28^{\circ} 48^{\prime} \mathrm{N}, 99^{\circ} 59^{\prime} \mathrm{W}\right)$. Comment (TRH): this is earliest substantial 
occupation recognized at site. No diagnostic artifacts assoc; however, final occupation at site has triangular points (dart points?) and several specimens of tentative Zavala type point, of late prehistoric age (Hill \& Hester, 1971; Hester \& Hill, 1975).

\section{Black Dog Village series}

Charcoal, except where noted, from Black Dog Village site (41 HC 30; Keller, 1975; discussion, p 63-64), early Panhandle aspect site at confluence of Cottonwood Creek and Canadian R, $8 \mathrm{~km} \mathrm{~N}$ of Borger on State Hwy 207 in Texas Panhandle $\left(35^{\circ} 43^{\prime} 58^{\prime \prime} \mathrm{N}, 101^{\circ} 24^{\prime} 58^{\prime \prime} \mathrm{W}\right)$. Coll 1971 and subm by F A Weir, Texas Hwy Dept, Austin. Comments by J E Keller.

$\begin{array}{ccc}\text { Tx-1488. } & \text { Black Dog } 1 & 390 \pm 50 \\ \text { Tx-1489. } & \text { Black Dog } 2 & 510 \pm 60 \\ \text { Tx-1490. } & \text { Black Dog } 3 & 470 \pm 60 \\ \text { Tx-1491. } & \text { Black Dog } 4 & 460 \pm 60\end{array}$

All above samples from Feature 6, Structure 4, round pit house or earth lodge, not typical of Panhandle aspect, below Structure 2 (see Tx-1493, below). Probably earliest structure on site.

Tx-1493. Black Dog 10 $280 \pm 150$

Structure 4, Feature 13, Hearth; $0.46 \mathrm{~m}$ below surface. Later than Structure 4, Feature 6 (Tx-1488-1491, above).

Tx-1495. Black Dog 12

$$
\mathbf{3 0 0} \pm \mathbf{5 0}
$$

Structure 5 (Big House): floor fill from SE corner. Only typical Panhandle aspect structure, and probably latest structure at site.

Tx-1496. Black Dog 14

$590 \pm 60$

Structure 5; floor fill.

\section{Tx-1497. Black Dog 17}

$610 \pm 50$

Structure 5; surface of altar.

Tx-1512. Black Dog 16

$980 \pm 170$

Structure 5, N Central post hole.

Tx-1513. Black Dog 18

$420 \pm 70$

Feature 17; fill of trash pit immediately S of Structure $3,4.6 \mathrm{~m} \mathrm{E}$ of entry of Structure 5 (Big House); may be assoc with Structure 5.

Tx-1498A. Black Dog 19A

$\mathbf{5 0 0} \pm \mathbf{7 0}$

Bone apatite.

Tx-1498B. Black Dog 19B

$1110 \pm 200$

Bone collagen. Feature 17; trash pit. 
Tx-1499. Black Dog 20

Feature 17; trash pit.

General Comment: dates indicate 3 periods of settlement, a classic Panhandle aspect occupation and 2 occupations, less well defined. At end of Panhandle aspect occupation, an occupation was assoc with pit house, which, while different architecturally, was similar in artifactual materials. Afterwards, site was reoccupied by a group which built or reutilized Structure 2. Dates do not support a continuous Panhandle aspect occupation.

After above samples were dated, 2nd series was subm, including several portions of same samples as above. Dates range 700 to $1000 \mathrm{yr}$ earlier than those above, but in same general relationships to one another. Storage circumstances were checked. Although specimens were in polyethylene containers, they appear to have been contaminated by dead $\mathrm{C}$ in organic insecticide used to fumigate storeroom. Second series, Tx-17101719, is considered invalid and is therefore not reported.

\section{Anthon series, Texas}

Charcoal from Anthon site (41 UV 60), 6.4km SW of Uvalde city limits on 1st terrace of proposed crossing of Nueces R by FM 481, Uvalde Co, SW Texas $\left(29^{\circ} 07^{\prime} 21^{\prime \prime} \mathrm{N}, 99^{\circ} 53^{\prime} 13^{\prime \prime} \mathrm{W}\right)$. Coll 1975 and subm by F A Weir. Nos. in titles following sample nos. indicate depth in $\mathrm{ft}$.

Tx-2378. Anthon 7, 1.65-2

Sq N187.2/E75, 0.5 to $0.6 \mathrm{~m}$ depth, upper midden, assoc with Frio point and Feature 3 hearth.

Tx-2380. Anthon 23, 3.25-3.5

$2210 \pm 60$

Sq N108.8/E118, 0.9 to $1 \mathrm{~m}$ depth, upper portion of lower midden.

Tx-2381. Anthon 24, 3.95

Sq N104/E123.5, 1.2m depth, lower midden.

$3000 \pm 60$

Tx-2383. Anthon 42, 0.5

Sq N101.4/E135.5, 0.15m depth.

$$
830 \pm 70
$$

Tx-2384. Anthon 43, 2

Sq N108.4/E117, 0.6m depth, same level as Feature 15 hearth.

Tx-2385. Anthon 62, 3.35-3.5

$3120 \pm 70$

Sq N190.6/E204, 1 to $1.1 \mathrm{~m}$ depth, lower midden, Feature 25, assoc with Kinney and Pedernales points.

Tx-2442. Anthon 16, 3.9

$3520 \pm 60$ hearths.

Sq N105/E82 and surrounding area, ca $1.2 \mathrm{~m}$ depth, Feature 16

Tx-2443. Anthon 46, 1.25-1.75

Sq N95-97/E140-142, .38 to .5m depth, upper midden.

$800 \pm 50$ 
Tx-2444. Anthon 64, 0.8-1

$680 \pm 50$ points.

Sq N171.7/E25, 0.2 to $0.3 \mathrm{~m}$ depth, upper midden, assoc with Ensor

General Comment (FAW): earliest deposits of lower midden, dated by Tx-2381, -2385, \& -2442, indicate Middle Archaic, Round Rock phase, occupation. Assoc of Tx-2378 \& -2384 with Late Archaic, San Marcos and Twirl Sisters phases points agrees with other dates for this stage from Central and $W$ Texas. Post-Archaic deposits of upper midden are dated by Tx-2444 \& -2383. Tx-2443 is assoc with Post-Archaic and Late Archaic deposits because of depositional disturbance. For definition of Archaic phases, see Weir (1976).

\section{Perro Salvaje site series, Texas}

Charcoal from Midden B, Perro Salvaje site (41 SU 2), Late Archaic burned-rock ring midden $4.8 \mathrm{~km} \mathrm{E}$ of Sonora on hill $\mathrm{S}$ of dry tributary

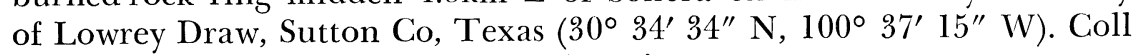
1971 by E R Prewitt and subm by F A Weir.

Tx-1507. Perro Salvaje \#2 $910 \pm 60$

N470/E940, base of Level 2.

Tx-1508. Perro Salvaje \#3 $920 \pm 70$

N455/E940, Level 3.

Tx-1509. Perro Salvaje \#4

$860 \pm 60$

N455/E940, Level 3.

Tx-1510. Perro Salvaje \#5

$1040 \pm 60$

N450/E940, Level 4.

General Comment (FAW): dates are at least 500 yr later than expected for a Late Archaic site, although not late for ring middens. Possibly change from Archaic to Late Prehistoric took place later here than in Central Texas, or else the 2 stages overlap here.

\section{Three Dog site series, Texas}

Charcoal from Three Dog site (41 CX 95), Middle Archaic to NeoAmerican burned rock middens and assoc hearths, $28.9 \mathrm{~km} \mathrm{~W}$ of Ozona at crossing of Howard draw by Interstate Hwy 10, W central Crockett Co, Texas (30 41'32" N, 101 $\left.26^{\prime} 37^{\prime \prime} \mathrm{W}\right)$. Coll and subm 1972 by F A Weir and G L Moore, Texas Hwy Dept, Austin, Texas.

Tx-1703. Three Dog \#1

$780 \pm 90$

Feature \#2, within hearth.

Tx-1704. Three Dog \#2

$1980 \pm 500$

Feature \#21, within hearth.

Tx-1705. Three Dog \#3

$1660 \pm 70$

Feature \#2, outside hearth. 
Tx-1706. Three Dog \#4

$1020 \pm 140$

Feature \#6, outside hearth.

Tx-1707. Three Dog \#5

$820 \pm 70$

Feature \#6, within hearth.

Tx-1708. Three Dog \#6

$840 \pm 70$

Feature \#11, within hearth.

Tx-1709. Three Dog \#7

Feature \#11, under hearth.

$1430 \pm 60$

General Comment (FAW): dates apply only to Neo-American occupation; rest of site sequence could not be dated.

Tx-897. Bonfire 338, 439, 593, apatite

$9610 \pm 130$

Apatite fraction from bison bone, Bonfire Shelter (41 VV 218; Dibble and Lorrain, 1968), E side of Mile Canyon $1.6 \mathrm{~km}$ from Rio Grande R, E of Langtry, Val Verde Co, SW Texas $\left(29^{\circ} 48^{\prime} \mathrm{N}, 101^{\circ} 33^{\prime} \mathrm{W}\right)$. From Bone Bed 2, Feature 28, Component A, assoc with Folsom and unfluted lanceolate points. Coll 1964 and subm by D S Dibble, Texas Archeol Survey, Univ Texas, Austin. Comment (DSD): subm to cross-check apatite dating with previous dates on charcoal samples Tx-153 (10,230 \pm 160 ; R, 1965, v 7, p 304), Tx-657, -658 (9920 $\pm 150,10,100 \pm 300$; R, 1970, v 12, p 269). Present date a little later, but agrees with $T x-657$ and -658 within $2 \sigma$.

\section{Arenosa Shelter, Series 4, Texas}

Charcoal from Arenosa Shelter (4l VV 99), E bank Pecos R, 1.6km upstream from confluence with Rio Grande, Val Verde Co, Texas $\left(29^{\circ}\right.$ $42^{\prime} \mathrm{N}, 101^{\circ} 22^{\prime} \mathrm{W}$ ). Subm to provide additional dating control and check of previous dates. Coll 1965-1967 and subm by D S Dibble.

\section{Tx-1977. Arenosa 52, Stratum 11}

Stratum 11 (all levels), N202W210, assoc with Montell projectile points. Previous dates from stratum: Tx-286, $2410 \pm 140$, Tx-311, $2440 \pm$ 140 (R, 1967, v 9, p 444).

Tx-1975. Arenosa 58, Stratum 23

$3600 \pm 70$

Stratum 23, Diagonal Profile N210W200-180, sample from lens in middle of stratum; assoc with Middle Archaic assemblage including Langtry, Val Verde, and Almagre dart points. Previous date from stratum: Tx-287, $4080 \pm 380(\mathrm{R}, 1967$, v 9, p 444).

Tx-1979. Arenosa F13, Stratum 28

Hearth, Feature 13, on Stratum 28 living surface, assoc with Early Archaic assemblage including Pandale points. Same sample as SI-1401, $4630 \pm 100$ (R Stuckenrath, pers commun). 
Tx-1976. Arenosa 163, Stratum 28

$\mathbf{5 5 2 0} \pm \mathbf{2 8 0}$

Stratum 28, N199W174, on and within living debris; assoc with Pandale dart points. Previous dates: Tx-1979, above, and Tx-660, $4440 \pm$ 110, from underlying Stratum 30 (R, 1970, v 12, p 269).

General Comment (DSD): except Tx-1976 (note inconsistency with Tx660 , noted above), dates in this series are within $2 \sigma$ of previously dated samples and thus serve to substantiate assumed age of deposits.

\section{Conejo shelter series, Texas}

Wood charcoal from Conejo shelter (41 VV 162; Alexander, 1974), $0.5 \mathrm{~km}$ up from mouth of canyon emptying into Rio Grande $5 \mathrm{~km}$ above mouth of Pecos R, in Amistad Reservoir basin (29 $44^{\prime} \mathrm{N}, 101^{\circ} 24^{\prime} \mathrm{W}$ ). Coll 1968 by R K Alexander and subm by Alexander and D S Dibble, Texas Archeol Survey, Univ Texas, Austin. No. in title following sample designation indicates depth in in.

Tx-879. Conejo 12, 41-47

$12,280 \pm 170$

Units I and II, 1.04 to $1.19 \mathrm{~m}$ depth.

Tx-880. Conejo 29, 54

$13,920 \pm 210$

Unit Ic, $1.37 \mathrm{~m}$ depth; overlying Bone 32 .

Tx-881. Conejo 30

$14,300 \pm 220$

As with Tx-880, $0.18 \mathrm{~m} \mathrm{~N}$ of Bone 32 .

Tx-1757. Conejo H.11

$1810 \pm 70$

Agave leaf-bases, Lens H, N85/W106. Comment (DSD): date appears appropriate for Late Archaic deposition.

Tx-1758. Conejo 125.7

$6650 \pm 110$

Charcoal, Lens 125, N95-100/W105; in basal limestone dust deposit containing Early Barbed points; earliest occupation of site.

Tx-1759. Conejo 38.4

$2690 \pm 80$

Charcoal, Lens 38, N85/W105; dates beginning of Ensor point occupation. Comment (DSD): date somewhat early when compared with radiocarbon age of Ensor-producing strata at Arenosa shelter (41 VV 99) on Pecos R 5km from Conejo.

Tx-1760. Conejo 115.3

$4890 \pm 90$

Charcoal, Lens 115, N95/W95-100; dates approx beginning of Pandale point occupation. Comment (DSD): this date, Tx-1762 and -1763, all assoc with Pandale points, overlap within $1_{\sigma}$. Literal interpretation of age correspondence in Pandale-producing layers suggests rapid build-up of deposits during this occupation.

Tx-1761. Conejo 50.2

$3310 \pm 90$

Charcoal, Lens 50, N95/W95; major stratum with Val Verde points. Comment (DSD): date appears appropriate when compared with strata from Arenosa Shelter which produced Val Verde materials. 


\section{Tx-1762A. Conejo 103.3, charcoal $4950 \pm 70$ \\ Tx-1762B. Conejo 103.3, agave leaves $\quad 4590 \pm 90$}

Lens 103, N95/W95, approx center of Pandale point occupation. Comments (RKA): inconsistency of dates may reflect later introduction of older refuse into campfire; (EMD): fractionation may occur during photosynthesis in agave; this must be checked. However, Tx-1757 date on agave, above, seems appropriate.

\section{Tx-1763. Conejo 87.5}

$$
\mathbf{5 0 2 0} \pm \mathbf{8 0}
$$

Charcoal, Lens 87, N95/W100, approx end of Pandale occupation. Comment (DSD): age is generally within time range of Pandale point popularity at Arenosa Shelter but appears much too early for late manufacture of this style in region. See also Tx-1760, above.

General Comment (RKA): dates correspond well with sequence of projectile point forms as outlined by Story (1966).

\section{Perry's Ram's Head series, Texas}

Charcoal from Perry's Ram's Head site (41 PC 35), Transitional Archaic and late prehistoric burned-rock midden, on $\mathrm{N}$ tributary of Fourmile Draw $32 \mathrm{~km} \mathrm{~W}$ of Sheffield on U S Hwy 290, Pecos Co, W Texas $\left(30^{\circ} 50^{\prime} 29^{\prime \prime} \mathrm{N}, 102^{\circ} 02^{\prime} 50^{\prime \prime} \mathrm{W}\right)$. Coll 1971 by $\mathrm{E}$ R Prewitt and subm by F A Weir, Texas Hwy Dept, Austin, Texas. Comments by Weir.

Tx-1500. Perry's Ram's Head \# 1

$940 \pm 50$

Midden 1, N490/F550, Level 2, 0.5 to $1 \mathrm{ft}(0.15$ to $0.3 \mathrm{~m})$ below surface, central hearth. Comment: agrees with Tx-1507-1510 from Perro Salvaje, above, which also have Late Archaic artifact assoc. See comment for those dates.

Tx-1501. Perry's Ram's Head \#2

$\mathbf{3 4 0} \pm \mathbf{7 0}$

Midden 2, N490/E470, upper margins of Feature 8, central hearth.

Tx-1502. Perry's Ram's Head \#3

$410 \pm 60$

Midden 2, N490/E470, upper margins of Feature 8.

Tx-1503. Perry's Ram's Head \#4

$240 \pm 60$

Midden 2, N490/E470, bottom and E half of Feature 8.

Tx-1504. Perry's Ram's Head \#5

$350 \pm 50$

Midden 2, N490/E465, bottom and W half of Feature 8.

General Comment on Tx-1501-1504: dates agree with artifact types in indicating Midden 2 represents very late component, some $500 \mathrm{yr}$ later than Midden 1.

Tx-1505. Perry's Ram's Head \#6 $560 \pm 70$

Midden 2, N480/E475, SE portion of burned-rock ring around central hearth, Level 3, 0.4 to $0.6 \mathrm{ft}(0.12$ to $0.18 \mathrm{~m})$ below surface. Comment: earlier than Tx-1501-1504, which are assoc with same hearth, but still within estimated time for late prehistoric artifacts. 


\section{Squawteat Peak series}

Charcoal from 3 overlapping ring middens and assoc hearths, Squawteat Peak site (41 PC 14), S slope of Squawteat Peak, $53 \mathrm{~km} \mathrm{E}$ of Fort Stockton, Pecos Co, SW Texas $\left(30^{\circ} 53^{\prime} 30^{\prime \prime} \mathrm{N}, 102^{\circ} 19^{\prime} 50^{\prime \prime} \mathrm{W}\right)$. Late Archaic context including Frio and Ensor dart points and Perdiz and Alba-like arrow points. No ceramics. Coll 1974 and subm by F A Weir. Hyphenated nos. in titles indicate depth in $\mathrm{ft}$.

Tx-2053. Squawteat \#1, 1-1.5 $2120 \pm 70$

Feature 3, Unit S430/W580, Level 2, 0.3 to $0.45 \mathrm{~m}$ depth; from hearth adjacent to midden.

Tx-2054. Squawteat \#2, 4-4.5

$860 \pm 60$

Feature 1, Unit S455/W565, Level 9, 1.2 to $1.4 \mathrm{~m}$ depth; Midden \#1, base of oldest midden.

\section{Tx-2055. Squawteat \#3, 4.5-5}

$1050 \pm 60$

Feature 1, Unit S455/W565, Level 10, 1.4 to $1.5 \mathrm{~m}$ depth.

Tx-2056. Squawteat \#4, 0.5-1.

$630 \pm 100$

Pit of Midden \# 1, Unit S455/W545, Level 2, 0.15 to $0.3 \mathrm{~m}$ depth.

Tx-2057. Squawteat \#5, 1-1.5

$980 \pm 130$

Same as Tx-2056, above; Level 3, 0.3 to $0.45 \mathrm{~m}$ depth.

Tx-2058. Squawteat \#6, 1.5-2

$420 \pm 60$

Same as Tx-2056, above; Level 4, 0.45 to $0.6 \mathrm{~m}$ depth.

Tx-2059. Squawteat \# 7, 2-2.5

$420 \pm 70$

Same as Tx-2056, above; Level 5, 0.6 to $0.76 \mathrm{~m}$ depth.

Tx-2060. Squawteat \#8, 2.5-3

$610 \pm 50$

Same as Tx-2056, above; Level 6, 0.76 to $0.9 \mathrm{~m}$ depth.

Tx-2061. Squawteat \#9, 1-1.5

$450 \pm 60$

Pit of Midden \#1, Unit S460/W545, Level 3, 0.3 to $0.45 \mathrm{~m}$ depth.

Tx-2062. Squawteat \#10, 1.5-2

$650 \pm 70$

Pit of Midden \#2, Unit S460/W525, Level 4, 0.45 to $0.6 \mathrm{~m}$ depth.

Tx-2063. Squawteat \#11, 3-3.5

$800 \pm 70$

Same as Tx-2056, above; Level 7, 0.9 to $1 \mathrm{~m}$ depth.

General Comment (FAW): Tx-2053 applies to Late Archaic occupation preceding main activity in late prehistoric, development of ring middens, to which Tx-2054-2063 refer.

\section{Kaw Reservoir Basin, Oklahoma}

Charred wood from sites in Kaw Reservoir basin on Arkansas R, Kay Co, N Oklahoma. Coll 1972 and 1975 and subm by C L Rohrbaugh, except as noted. 


\section{Tx-1911. Vickery 1}

Feature 1, N5-W2, Area A, 30 to $55 \mathrm{~cm}$ (12 to 22 in.) depth, L W Vickery site (34 KA 41; Rohrbaugh, 1974a, p 31-74; discussion, p 50), Plains Woodland site, $10.4 \mathrm{~km} \mathrm{~N}, 2.4 \mathrm{~km} \mathrm{E}$ of Washuga on Little Beaver

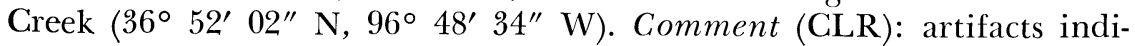
cate same age as Von Elm site (Tx-1907-1910, below). Date is earlier than previous estimates for late Plains Woodland. Agrees with Tx-1910 from Von Elm, but not with other Von Elm dates.

\section{Tx-1782. Freeman C1}

$$
\mathbf{5 3 0} \pm \mathbf{8 0}
$$

Feature 3, below Stratum 2, assoc with flint flakes, Freeman site (34 OS 59; Bastian, 1969, p 59-119; Rohrbaugh, 1974b, p 4), 10.4km S, $1.64 \mathrm{~km}$ $\mathrm{E}$ of Uncas near oxbow lake $\mathrm{N}$ of bend in Arkansas $\mathrm{R}$, on $\mathrm{E}$ bank ter-

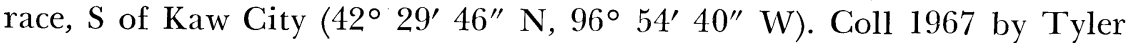
Bastian and subm by C L Rohrbaugh. Comment (CLR): date probably represents late Plains Woodland occupation.

\section{Von Elm series}

Samples from 2 pits in Area C of Von Elm site (34 KA 10) (Hartley, 1974; discussion, p 77, 80), S side Bear Creek ca $0.5 \mathrm{~km}$ above confluence with Arkansas R, 3.6km N, 2.4km E of Uncas $\left(36^{\circ} 40^{\prime} 42^{\prime \prime} \mathrm{N}, 95^{\circ} 54^{\prime}\right.$ $\left.21^{\prime \prime} \mathrm{W}\right)$.

\section{Tx-1907. Von Elm 1}

$$
1750 \pm 80
$$

Feature 2, Sq W30, fill of pit below 16 in. $(40 \mathrm{~cm})$ depth.

\section{Tx-1908. Von Elm 2}

$1360 \pm 60$

Same provenience as Tx-1907, Sq W31.

\section{Tx-1909. Von Elm 3}

$1740 \pm 60$

Feature 2 baulk, 8 to 30 in. (20 to $75 \mathrm{~cm}$ ) depth.

General Comment on Tx-1907-1909 (JDH): dates consistent with Plains Woodland occupation of $\mathrm{N}$ central Oklahoma, though in view of close agreement of Tx-1907 and -1909, -1908 may be falsely late. Dates suggest earlier occurrence of Plains Woodland in N Central Oklahoma than previously recognized.

\section{Tx-1910. Von Elm 4}

Feature 3, Sq S5-W18, 25 to 26 in. $(62.5$ to $65 \mathrm{~cm})$ depth. Comment (JDH): date consistent with Plains Woodland occupation.

\section{Daniels series}

Samples from Daniels site (34 KA 77; Rohrbaugh, 1973b, p 3-32; Rohrbaugh, 1974b, p 4-5), on bank of Coon Creek $1.6 \mathrm{~km}$ NW of confluence with Arkansas R, $1.6 \mathrm{~km} \mathrm{E}, 0.4 \mathrm{~km} \mathrm{~S}$ of Uncas $\left(36^{\circ} 47^{\prime} 30^{\prime \prime} \mathrm{N}\right.$, $\left.96^{\circ} 55^{\prime} \mathrm{W}\right)$. 
Tx-1780. Daniels A

Area A; from rocks at base of small hearth, 12 to 14 in. (30 to $35 \mathrm{~cm}$ ) depth, assoc with cord marked and bone tempered sherd and "turtle backed" plano-convex scrapers.

\section{Tx-1781. Daniels B}

$1060 \pm 100$

Area B; in fill of pit, Feature 1, 30 to 36 in. (75 to $90 \mathrm{~cm}$ ) depth, assoc with sand and clay tempered ceramics, Washita and Scallorn points, and bone tools.

General Comment (CLR): dates probably indicate late Plains Woodland component, at least in Area B. Relative lack of ceramics in Area A does not indicate such a late date, but Area A may represent special purpose, aceramic, late Plains Woodland manifestation.

\section{Hammons series}

Samples from Hammons site (34 KA 20), ca $12 \mathrm{~km} \mathrm{E}$ and $8 \mathrm{~km} \mathrm{~N}$ of Newkirk, along E bank of Chilocco Creek ( $36^{\circ} 58^{\prime} \mathrm{N}, 96^{\circ} 57^{\prime} \mathrm{W}$ ). Coll and subm by Wayne Young, Oklahoma R Basin Survey.

$\begin{array}{lll}\text { Tx-2352. } & \text { 34Ka-20/330 } & 1600 \pm 80\end{array}$ midden.

Feature 1, Sq S11E5, 24 in. $(60 \mathrm{~cm})$ depth; trash pit at bottom of

Tx-2353. 34Ka-20/329

$1870 \pm 70$

Same location as Tx-2352, above.

Tx-2354. 34Ka-20/136

$1810 \pm 190$

Feature 2, Sq S11E4, 24 in. $(60 \mathrm{~cm})$ depth; concentration of burned limestone at bottom of midden.

\section{Tx-2355. 34Ka-20/159}

$1470 \pm 130$

Level 9, Sq S12E3, 54 in. $(137 \mathrm{~cm})$ depth; sandy zone yielding stamped sherds and Williams points.

General Comment (WY): dates, which were expected to reflect separate Plains Village and Middle Woodland occupations, seem to reflect only a general Woodland period occupation.

\section{Bryson-Paddock series}

Samples from Bryson-Paddock site (34 KA 5), ca $11 \mathrm{~km} \mathrm{E}$ and $4 \mathrm{~km}$ $\mathrm{N}$ of Newkirk (36 $\left.56^{\circ} \mathrm{N}, 96^{\circ} 57^{\prime} 30^{\prime \prime} \mathrm{W}\right)$, in Kaw Reservoir basin. All samples assoc with protohistoric occupation with some European trade goods; thought to be Wichita Indians. Coll and subm by J D Hartley.

Tx-2356. Ka-5/500A

Modern

Grid A, Sqs S6-E4 \& S7-E4, Feature 5.

Tx-2357. Ka-5/500B

Modern

Same location as Tx-2356, above. 
Tx-2358. Ka-5/524

Grid A, Sq N9--W11, Structure A, Post Hole \#31.

Modern

Tx-2359. Ka-5/499

$190 \pm 60$

Grid A, intersec of Sqs N9-W3, N10-W2, N9-W4, N10-W4, 16 to 20 in. $(45$ to $60 \mathrm{~cm})$ depth.

Tx-2360. Ka-5/502

$290 \pm 70$

Grid B, Sqs S2-E1 \& S3-E1, 15 in. $(38 \mathrm{~cm})$ depth; pit S of Structure B (Feature 8).

Tx-2361. Ka-5/389

Modern

Grid B, Sqs 0-E1, Structure B, Level 4,18 to 24 in. (45 to $60 \mathrm{~cm})$ depth; overlying house floor.

General Comment (JDH): rodent activity may be responsible for modern dates of Tx-2358 \& -2361. Artifactual data suggest AD 1690 to 1740 time for Tx-2356 \& -2357. Related data suggest that context of Tx-2360 was much earlier than rest of site; date supports this. More abundant European trade material from context of Tx-2359 suggests that Grid A area was later than Grid B.

\section{Other Oklahoma, Florida, New Mexico, Montana}

\section{Tx-1483. McKensie, 78, Oklahoma}

$1890 \pm 70$

Charred wood from Area A, Sq N9-0, Level 4, McKensie site (34 CH 89 ), W bank Kiamichi R, $0.8 \mathrm{~km} \mathrm{E}$ of confluence with One Creek,

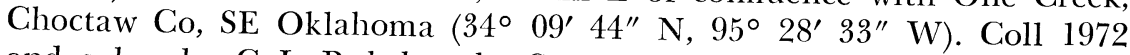
and subm by C L Rohrbaugh. Comment (CLR): initially thought to represent shift from Middle to Late Archaic, but date is much too late and possibly represents contamination from upper levels.

\section{Payne series, Oklahoma}

Charred wood from Payne site (34 CH 53; Rohrbaugh, 1973a, p 2-75, 159-166; Rohrbaugh, 1974b, p 2-3), ca $0.8 \mathrm{~km} \mathrm{~S}$ of Long Creek, $4.5 \mathrm{~km}$ upstream from confluence with Kiamichi R, in Hugo Reservoir basin, SE Oklahoma (34 04' 13" N, 95 26' 59" W). Early Caddo (Caddo I), Apple phase. Coll 1972 and subm by C L Rohrbaugh.

\section{Tx-1777. Payne 3}

Upper fill (Stratum 1) of large refuse pit, Feature 3.

$$
910 \pm 90
$$

Tx-1481. Payne 1

$$
1070 \pm 50
$$

Main fill (Stratum 4) of pit, Feature 3. Separated from upper fill (Tx1777, above) by baked clay lens.

Tx-1482. Payne 2

$$
880 \pm 40
$$

Compacted fill (Stratum 5) at bottom of pit, Feature 3. Below and distinct from Stratum 4 (Tx-1481, above). 
Tx-1779. Payne 5

$1280 \pm 120$

Middle layer (Stratum 1) above main fill of pit, Feature 5.

Tx-1778. Payne 4

$470 \pm 80$

Sq N6-E4, Level 4, base of midden deposit.

General Comment (CLR): material culture and features indicate Apple phase context in Red $\mathrm{R}$ drainage contemporary with late Alto and Harlan phases. Nelson focus (Bell \& Baerreis, 1951, p 48-53) is similar. Ceramics related to Coles Creek; one sherd was Marksville Stamped. Tx-1779 is almost certainly too early, and Tx-1778 too late, for this context; probably do not represent occupation dates. The 3 dates from Feature 3, despite stratigraphic reversal, probably represent whole span of occupation, ca AD 900 to 1100.

\section{Pat Boyd Place series, Oklahoma}

Charcoal, except where noted, from Pat Boyd Place (34 CH 113; Rohrbaugh, 1973a, p 77-142, 168-177; Rohrbaugh, 1974b, p 3), late Gibson aspect (Caddo II) site, $1.6 \mathrm{~km} \mathrm{E,} 1.6 \mathrm{~km} \mathrm{~N}$ of Sawyer, W bank Kiamichi R, in Hugo Reservoir basin, SE Oklahoma $\left(34^{\circ} 00^{\prime} 41^{\prime \prime} \mathrm{N}\right.$, $95^{\circ} 23^{\prime} 51^{\prime \prime} \mathrm{W}$ ). Coll 1972 and subm by C L Rohrbaugh.

\section{Tx-1484. Pat Boyd 1}

$660 \pm 40$

Area B, Sqs 0-0 and 0-S1; from upper fill of small pit.

Tx-1485. Pat Boyd 2

$690 \pm 50$

Wood; Area B, Sq S1-W1, Post Hole \#99.

Tx-1486. Pat Boyd 3

$1340 \pm 140$

Graded Strip B, House 1, Post Hole \#99.

Tx-1487. Pat Boyd 4

$640 \pm 40$

Graded Strip B, House 1, Fire Hearth 1. Comment (CLR): archaeomagnetic date from this feature agrees well with this date; probably reflects date of house more accurately than Tx-1486, above.

General Comment (CLR): Nelson focus (Bell \& Baerreis, 1951) similar to this site. Tx-1486 undoubtedly too early for Sanders phase component, probably dates between AD 1100 and 1300 in this area; age estimate is supported by Tx-1484-1486.

\section{Little Salt Spring series, Florida}

Samples from Little Salt Spring site (8 UW 72) in sink hole within city limits $4.8 \mathrm{~km} \mathrm{SE}$ of center of North Port, S Florida $\left(27^{\circ} 04^{\prime} 26^{\prime \prime} \mathrm{N}\right.$, $\left.82^{\circ} 14^{\prime} \mathrm{W}\right)$. Coll 1975 and subm by C J Clausen, Little Salt Spring Research Facility, North Port, Florida. Comments by Clausen.

Tx-2335. \#2120

$$
13,450 \pm 190
$$

Bone fragments of extinct variety of giant ground tortoise on ledge $27 \mathrm{~m}$ below surface. Comment: date indicates approx time local ground 
water level in this area rose past this elevation $(21 \mathrm{~m}$ below mean sea level) in response to generally rising sea level following late Wisconsin glaciation. Pointed wooden stake assoc with tortoise remains indicates man was present in area.

Tx-2336. \#2109

Modern

Partially burned stick from upper layer of loose sediment on $27 \mathrm{~m}$ ledge. Comment: unexpectedly modern date destroys hypothesis that recent organic debris could not settle on ledge and suggests that massive water column in feature, thought to be relatively still, contained weak currents capable of laterally displacing slow downward drift of waterlogged organic material sufficiently to permit deposition on ledge.

Tx-2337. \#2119

Modern

Wood fragments on E $21.3 \mathrm{~m}$ ledge, Sta \#8. Comment: see Tx-2336, above. Subsequent controlled release of fluoricene dye at various locations and depths in spring indicated discernible movement in water in central cavity of spring.

\section{X29SF2 series, New Mexico}

Charcoal from pit structure, Site X29SF2, 3.15km SE of Nambe Pueblo, $0.35 \mathrm{~km}$ N of confluence of Rio En Medio and Rio Nambe, New Mexico (35 51' 57" N, $105^{\circ} 56^{\prime} 25^{\prime \prime} \mathrm{W}$ ). Preceramic occupation. Coll 1973 by $\mathrm{T} N$ Sanders and subm by M S Henderson, Archaeol Research Lab, Anthropol Dept, Southern Methodist Univ, Dallas, Texas. Comments by Henderson.

Tx-1992. X29SF2, 31-2

$1340 \pm 80$

Feature 31, Level 3, occupation level above sterile floor. Sample from possible roof support hole. Comment: consistent with Tx-1994, below. Nine small $(<2 \mathrm{~cm}$ length) obsidian corner- and basal-notched projectile points from fill and occupation level of structure agree with late preceramic date.

\section{Tx-1993. X29SF2, 49-2}

$$
2510 \pm 90
$$

Feature 49, Level 3, N perimeter of occupation surface, $2 \mathrm{~m}$ below ground surface in pit fill below occupation surface. Comment: date suggests early preceramic occupation, but absence of large $(>2 \mathrm{~cm}$ length), expanding-stem projectile points in site makes date seem too late. Presence of burned corn cupules, kernels, and cobs in flotation sample from this provenience suggests early use of maize; but seeds of Black Medic (Medicago lupulina) supposedly of recent European introduction, make context seem mixed. This would explain lack of agreement with Tx-1992 and -1994, which are presumably meaningful for this context.

Tx-1994. X29SF2, 50-2

$1550 \pm 60$

Feature 50, Level 3, contiguous with Feature 49, Level 3 (Tx-1993, above). Comment: see Tx-1992 and -1993, above. 
Charcoal from Drifters Shelter site (24 BH 1727), Late Prehistoric site, $32 \mathrm{~km} \mathrm{~N}$ of Sheridan, Wyoming, on Youngs Creek, Crow Indian Reservation, SE Montana (45 $\left.01^{\prime} 34^{\prime \prime} \mathrm{N}, 107^{\circ} 00^{\prime} 19^{\prime \prime} \mathrm{W}\right)$. Sample from buried hearth, Unit 1N0W, on or below outer edge of shelter overhang, 20 to $30 \mathrm{~cm}$ depth. Coll 1974 and subm by D \& L Fredlund, Min Research Center, Montana Tech Foundation, Butte, Montana. Comment (LF): date supports late prehistoric cultural assignment.

\section{Tx-2368. Thrower Seed Ring \# 1, Montana}

Modern

Charcoal from hearth in center of stone circle, Thrower Seed Ring site (24 BH 149), 40km NE of Hardin on knob hill adjacent to $\mathrm{W}$ fork of Sarpy Creek, SE Montana (45 $46^{\prime} 22^{\prime \prime}$ N, $107^{\circ} 07^{\prime} 03^{\prime \prime}$ W). Coll and subm by D \& L Fredlund. Comment (LBF): date indicates historic period. No diagnostic artifact assoc.

\section{Bensons Butte series, Montana}

Charcoal from Bensons Butte site (24 BH 1726), 32km N of Sheridan, Wyoming, on Youngs Creek, SE Montana $\left(45^{\prime} 01^{\prime} 34^{\prime \prime} \mathrm{N}, 107^{\circ} 01^{\prime} 13^{\prime \prime} \mathrm{W}\right)$. Coll 1975 and subm by D \& L Fredlund.

Tx-2362. Bensons Butte \#1

$1050 \pm 60$

Unit $11 \mathrm{~N} 37 \mathrm{~W}, 55$ to $90 \mathrm{~cm}$ depth, base of cultural deposits.

\section{Tx-2363. Bensons Butte \#2}

$1180 \pm 70$

Unit $10 \mathrm{~N} 34 \mathrm{~W}, 30$ to $40 \mathrm{~cm}$ depth, assoc with middle and late prehistoric projectile points.

Tx-2364. Bensons Butte \#3

$1110 \pm 70$

Unit $8 \mathrm{~N} 34 \mathrm{~W}, 27$ to $37 \mathrm{~cm}$ depth.

Tx-2365. Bensons Butte \#4

$1170 \pm 70$

Unit $19 \mathrm{~N} 29 \mathrm{~W}, 20 \mathrm{~cm}$ depth, assoc with late prehistoric artifact types.

Tx-2366. Bensons Butte $\# \mathbf{5}$

$1250 \pm 80$

Unit $3 \mathrm{~S} 0 \mathrm{~W}$ and hearth area, 20 to $30 \mathrm{~cm}$ depth, assoc with late prehistoric projectile points.

General Comment (LF): inconsistency of depths and assocs due to varying depths of fire-hearth pits and of sandy matrix. Dates support artifact assocs.

\section{Amy's Shelter series}

\section{Nevada}

Charcoal fragments scattered in fill, from Amy's Shelter (26 WP 230), S side Smith Creek Canyon, ca $29 \mathrm{~km} \mathrm{~N}$ of crossing of NevadaUtah border by US Hwy $50\left(39^{\circ} 20^{\prime} \mathrm{N}, 114^{\circ} 05^{\prime} \mathrm{W}\right)$. Coll 1972 and subm by Ruth Gruhn, Dept Anthropol, Univ Alberta, Edmonton. Depths are below Stake C11. 
Tx-1425. Amy's Shelter, 168 $1550 \pm 70$

Brown III zone in C10/C11 baulk, depth ca 15 to $40 \mathrm{~cm}$. Beginning of late prehistoric period; small corner-notched or barbed projectile points.

Tx-1426. Amy's Shelter, 222

$\mathbf{2 8 3 0} \pm \mathbf{8 0}$

Brown V zone in C10/C11 baulk, depth ca 100 to $140 \mathrm{~cm}$. Elko cornernotched projectile points.

Tx-1428. Amy's Shelter, 281 $3720 \pm 70$

Brown VII zone in C10/C11 baulk, depth ca 180 to $200 \mathrm{~cm}$. Stemmed indented-base projectile points and small flake tools.

Tx-1429. Amy's Shelter, 392

$4420 \pm 90$

Brown IX zone in Sq C11, depth ca 280 to $310 \mathrm{~cm}$. Humboldt concave-based projectile points and small flake tools. Earliest intensive occupation.

Tx-1430. Amy's Shelter, 397

$4950 \pm 110$

From surface and fill of Brown X zone in Sqs C10 and C11, depth ca 310 to $320 \mathrm{~cm}$. Deepest occupational unit: a few obsidian and chalcedony flakes.

General Comment (RG): series is consistent, indicating beginning of stratigraphic sequence ca 3000 BC. Dates on assoc artifact types correspond with time ranges of such types at other sites in central Great Basin.

\section{Smith Creek Cave series}

Charcoal from Lake Mohave culture living floor, Smith Creek Cave (26 WP 46), N side Smith Creek Canyon ca $29 \mathrm{~km} \mathrm{~N}$ of Crossing of Nevada-Utah border by US Hwy $50\left(39^{\circ} 21^{\prime} \mathrm{N}, 114^{\circ} 05^{\prime} \mathrm{W}\right)$. Coll 1971 and subm by A L Bryan, Dept Anthropol, Univ Alberta, Edmonton.

Tx-1420. Smith Creek Cave 8

$9940 \pm 160$

Test Pit 6, Hearth 9, Level 4, 21 to $26 \mathrm{~cm}$ below surface.

Tx-1421. Smith Creek Cave 10

$11,680 \pm 160$

Test Pit 5, scattered fragments from living floor.

Tx-1637. Smith Creek Cave 7

$11,140 \pm 200$

Test Pit 4.

Tx-1638. Smith Creek Cave 9

$10,330 \pm 190$

Test Pit 6, Hearth 12.

Tx-1639. Smith Creek Cave 12

Test Pits 2 and 5, and Baulk Extension 1/2; Layer 5.

$28,650 \pm 760$

General Comment (ALB): 1st 4 dates are from stratified occupation zone $25 \mathrm{~cm}$ thick at front of cave containing hair of artiodactyl, bison, and guanaco; bones of sheep, antelope, small mammals; tools for processing 
skin and bone; and re-used Lake Mohave point bases similar to Cougar Mt points (Layton, 1972, p 13, fig 1, type 1). Later excavation of same occupation area yielded complementary dates GaK-5442-5446: 10,666 \pm $220,10,630 \pm 190,9800 \pm 190,10,570 \pm 160,9280 \pm 160$ (Bryan, pers commun). Only last date of series seems out of line. Other dates indicate that skin and bone processing activity area was used between 10,500 and $11,000 \mathrm{yr}$ BP, although occasional occupation may have occurred as early as 11,500 and as late as 10,000 yr ago.

\section{Kachina Cave series}

Samples from Excavation Unit C-10, Kachina Cave (26 WP 69), $\mathrm{N}$ side Smith Creek Canyon, ca $29 \mathrm{~km} \mathrm{~N}$ of crossing of Nevada-Utah border by US Hwy $50\left(39^{\circ} 21^{\prime} \mathrm{N}, 114^{\circ} 06^{\prime} \mathrm{W}\right)$. Coll 1971 and subm by D R Tuohy, Dept Anthropol, Nevada State Mus, Carson City, Nevada. Depths are below Stake C10.

\section{Tx-1422. Kachina Cave 129}

$2090 \pm 80$

Charcoal; Feature 4, Layer 8, depth 148 to $175 \mathrm{~cm}$. Believed to correlate with Brown V zone of Amy's Shelter (Tx-1426, above). Comment (DRT): dates agrees with other evidence, and projectile point series from both sites appear to correlate.

\section{Tx-1424A. Kachina Cave 191a, corncobs} $680 \pm 70$

Tx-1424B. Kachina Cave 191b, wood $1500 \pm 150$

From Parowan Fremont culture living floor and hearth, depth $36 \mathrm{~cm}$. Comment (DRT): allowing for $200 \mathrm{yr}$ correlation (to AD 1070) due to fractionation in photosynthesis in corn, Tx-1424A is consistent with archaeol assocs. Anomalously early age of Tx-1424B may be due to mixing of floor deposits during earlier excavations (Harrington, 1932, p 150) or to use by aboriginal inhabitants of old wood washed in by creek.

\section{Central and South America}

\section{Los Tapiales series, Guatemala}

Charcoal from Los Tapiales (906454), Paleo-Indian site, ca $1.5 \mathrm{~km} \mathrm{E}$ of Totonicapán, Guatemala (14 $\left.53^{\prime} \mathrm{N}, 91^{\circ} 15^{\prime} \mathrm{W}\right)$. Coll 1972 and subm by A L Bryan.

\section{Tx-1630. Los Tapiales A}

Sq H-10, 60 to $65 \mathrm{~cm}$ depth, assoc with burned wood from dark brown loam above buried soil.

\section{Tx-1631. Los Tapiales B}

Sq I-10, 100 to $110 \mathrm{~cm}$ depth, lowest occupation zone beneath soil. General Comment (ALB): dates agree stratigraphically. With other dates now available (GaK-4890, $9860 \pm$ 185; GaK-4886, $4790 \pm$ 100; (Bryan, pers commun) they indicate gradual accumulation of sediments. Tx-1631 is assoc with Paleo-Indian assemblage including base of fluted point, 
burins, gravers, biface fragments, endscrapers, sidescrapers, with flake industry mainly of basalt. No faunal remains preserved.

\section{La Piedra de Coyote series, Guatemala}

Charcoal from La Piedra de Coyote (873469), near Totonicapán, Guatemala $\left(14^{\circ} 53^{\prime} \mathrm{N}, 91^{\circ} 16^{\prime} \mathrm{W}\right)$; subm to establish temporal correlation with Los Tapiales site (Tx-1630, -1631, above), ca 5km distant. All samples are from oldest occupation level of site. Coll 1972 and subm by A L Bryan.

Tx-1632. La Piedra de Coyote C(1)

$10,650 \pm 1350$

Sq P-20, 100 to $110 \mathrm{~cm}$ depth.

Tx-1633. La Piedra de Coyote C(2)

$5320 \pm 90$

Sq $0-20,100$ to $110 \mathrm{~cm}$ depth.

Tx-1634. La Piedra de Coyote C(3)

$10,020 \pm 260$

Sq R-20, 100 to $110 \mathrm{~cm}$ depth.

Tx-1635. La Piedra de Coyote D

$9430 \pm 120$

Sq P-20, 90 to $100 \mathrm{~cm}$ depth.

General Comment (ALB): dates agree stratigraphically. Oldest dates, Tx-1632, -1634, confirm observed relationship in flake typology with Los Tapiales, Tx-1630, -1631, above, and indicate that the 2 sites were neighboring Paleo-Indian camps occupied more or less contemporaneously. Reason for inconsistent date of Tx-1633 is not known.

\section{Ilopango series, E1 Salvador}

Samples from sites in El Salvador beneath Ilopango volcanic ash layer; coll to date eruption at beginning of our era which resulted in widespread destruction of Preclassic highland Maya sites. Coll 1975 and subm by P D Sheets, Dept Anthropol, Univ Colorado, Boulder, Colorado.

Tx-2323. Santiago Texacuango \# 1

$2500 \pm 150$

Charcoal from Santiago Texacuango site (SS12t), $1 \mathrm{~km} \mathrm{E} \mathrm{of} \mathrm{Santiago}$ Texacuango on rd between Finca Agua Rica and Finca Suiza, 2km SW of Lake Ilopango (13 $\left.38^{\prime} \mathrm{N}, 89^{\circ} 07^{\prime} \mathrm{W}\right)$. Comment (PDS): apparently dates smaller, hitherto unknown eruption, earlier than one under study.

Tx-2324. Laguna Seca \#1

$1970 \pm 60$

Humic soil from Test Pit LS1-1, Laguna Seca site (SA2t), at base of Laguna Seca Caldera, $701 \mathrm{~m}$ alt, $1 \mathrm{~km}$ SE of Chalchuapa $\left(13^{\circ} 58^{\prime} \mathrm{N}, 89^{\circ}\right.$ $\left.41^{\prime} \mathrm{W}\right)$. Comment (PDS): supports assoc archaeol evidence for date of eruption.

Tx-1555. Miraflores Alto, Ecuador

$\mathbf{2 5 8 0} \pm \mathbf{7 0}$

Charcoal from 3rd stratigraphic level, X, Excavation 1, Miraflores Alto site, on slope of Pichincha volcano near Quito, Ecuador $\left(0^{\circ} 12^{\prime} 57^{\prime \prime}\right.$ S, $\left.78^{\circ} 29^{\prime} 56^{\prime \prime} \mathrm{W}\right)$. Assoc with Panzaleo occupation, a regional develop- 
ment in Highlands. Coll and subm by Juan Cueva Jaramillo, Mus Arqueol, Banco Central, Quito, via R E Bell, Dept Anthropol, Univ Oklahoma, Norman. Comment (REB): date is comparable to Tx-1134 and $-1135(2060 \pm 110,2170 \pm 100 ; \mathrm{R}, 1975, \mathrm{v} 17, \mathrm{p} 95)$ from Panzaleo ceramics at Santa Lucia site.

Tx-1824. Pashash J, Peru $1590 \pm 60$

Charcoal from Cut 12, Level 4, NE corner inner chamber, La Capilla temple, Pashash site, $2 \mathrm{~km} \mathrm{~S}$ of Cabana, Prov Pallasca, Ancash, Peru $\left(08^{\circ} 24^{\prime} \mathrm{S}, 78^{\circ} 03^{\prime} \mathrm{W}\right)$. From fill above late Recuay (Pashash Recauy period, Wari phase) burial; Recuay ceramics. Coll 1973 and subm by Terence Grieder, Dept Art, Univ Texas, Austin. Comment (TG): should be same age as $\mathrm{Tx}-1329,1400 \pm 60(\mathrm{R}, 1975, \mathrm{v} 17, \mathrm{p} 94)$ which was from same level in adjoining Cut 10. Earlier age of Tx-1824 suggests this sample was already old (early Recuay, Aurora phase) when it was included in fill.

\section{Cochabamba series, Bolivia}

Human bone from excavations in Cochabamba Valley and neighboring mountainside, $3.2 \mathrm{~km}$ from Cliza, $48 \mathrm{~km} \mathrm{SE}$ of Cochabamba, Bolivia $\left(17^{\circ} 30^{\prime} \mathrm{S}, 66^{\circ} \mathrm{W}\right)$. Subm by G Bryne de Caballero, Mus Arqueol, Univ Boliviana Mayor de San Simon, Cochabamba, Bolivia.

Tx-1817A. Santa Lucía, apatite $2040 \pm 60$

Tx-1817B. Santa Lucía, collagen $\quad 1550 \pm 330$

Below Tiwanacu stratum, assoc with unpainted pottery, stone and metal artifacts, in Excavación de Santa Lucia. Should establish date for pre-Tiwanacu culture. Site is in eroded part of complex of mounds which also includes Excavación de Cruzpata (Tx-1818, below). Coll 1973 by G Byrne de Caballero. Comment (GBC): younger than expected, but not seriously so.

\section{Tx-1818A. Cruzpata, apatite}

Tx-1818B. Cruzpata, collagen

$2400 \pm 80$

$2 \mathrm{~m}$ level in Excavación de Cruzpata, part of large complex of mounds. Should establish date for Tiwanacu pottery. Coll by G Byrne de Caballero and $\mathrm{R}$ Urioste. Comment (GBC): dates are approx as expected.

Tx-1819A. Mesadilla, apatite

Tx-1819B. Mesadilla, collagen

Circular grave, $2.5 \mathrm{~m}$ level. Excavación de Mesadilla, on mountainside $3.2 \mathrm{~km} \mathrm{~N}$ of Cochabamba $\left(17^{\circ} 24^{\prime} \mathrm{S}, 66^{\circ} 09^{\prime} \mathrm{W}\right)$; should establish chronologic relationship between this site and Tiwanacu material in Cochabamba valley. Coll 1973 by G Byrne de Caballero and O Gonzalez. Comment (GBC): site was thought to be pre-Tiwanacu; date indicates it is Inca. 


\section{Veluška Tumba series, Yugoslavia}

\section{Europe}

Charcoal from Veluška Tumba, early Neolithic tumulus near Porodin, ca $18 \mathrm{~km} \mathrm{~S}$ of Bitola, Macedonia, Yugoslavia $\left(40^{\circ} 54^{\prime} \mathrm{N}, 21^{\circ} 22^{\prime} \mathrm{E}\right)$. Tumulus contained 4 cultural strata (phases) separated by deposits of leveling fill. Coll 1972 and subm by Vojislav Sanev, Dir, Natl Mus, Štip, Yugoslavia, via E M Davis, this lab.

Tx-1785. Veluška Tumba \#1

$6950 \pm 120$

Charred wood from Phase IV house, earliest occupation of site.

Tx-1786. Veluška Tumba \#2

$6890 \pm 140$

Charred wheat grains from house, Phase II (next to latest).

Tx-1809. Veluška Tumba \#3

$6900 \pm 90$

Charcoal from posts of house, Phase II.

General Comment (EMD): dates agree closely, and indicate that site was occupied for $250 \mathrm{yr}$ or less.

\section{Tx-1787. Lokalitet Tumba \#4, Yugoslavia}

$6760 \pm 110$

Charred wheat grains from early Neolithic house at Lokalitet Tumba, tumulus near Porodin (see Veluška Tumba series, above). Culture stylistically like Phases I and II of Veluška Tumba. Coll 1954 and subm by Vojislav Sanev. Comment (EMD): date agrees with Tx-1786-1809 , but suggests slightly later age.

\section{Golena Tumba series, Yugoslavia}

Charcoal from Golena Tumba, middle Neolithic tumulus near Trn, ca $20 \mathrm{~km} \mathrm{E}$ of Bitola, Macedonia, Yugoslavia $\left(41^{\circ} 02^{\prime} \mathrm{N}, 21^{\circ} 46^{\prime} \mathrm{E}\right)$. Coll 1973 and subm by Vojislav Sanev.

Tx-1788. Golena Tumba, \#5

$5640 \pm 90$

From Phase I house, latest occupation of site.

Tx-1789. Golena Tumba, \#6

$5670 \pm 90$

From same house as Tx-1788, above.

Tx-1790. Golena Tumba, \# 7

$5950 \pm 90$

From Phase II house, earliest occupation of site.

General Comment (EMD): Tx-1788 and -1789 agree closely and date Phase I, latest occupation, ca 3700 BC (uncorrected). Tx-1790 indicates Phase II was ca 300 yr earlier.

General Comment on dates Tx-1785-1790, -1809, Bitola area (EMD): dates indicate early Neolithic in this area has ${ }^{14} \mathrm{C}$ age (uncorrected) of early 5 th millennium BC; middle Neolithic is in early 4 th millennium. 


\section{Stobi series II, Yugoslavia}

Charcoal obtained by water separation from deposits at Stobi, Hellenistic and Roman site at junction of Crna $\mathrm{R}$ with Vardar R, S of Titov Veles, Macedonia, Yugoslavia $\left(41^{\circ} 33^{\prime} \mathrm{N}, 21^{\circ} 59^{\prime} \mathrm{E}\right)$. In comments, "corrected dates" are according to Damon et al, 1974. Previous Stobi dates are in R, 1975, v 17, p 96-98.

\section{Tx-2318. Stobi 57X75; Theater}

$$
\mathbf{2 8 5 0} \pm \mathbf{7 0}
$$

From fill of small pit, bottom of Theater Trench 16, below sterile stratum sealed by 1st and 2nd earthen floors of $\mathrm{E}$ Parodos beside podium of scene bldg; Lot 1684. Sherds in same fill are of prehistoric types, but sherd of later type is higher without discontinuity of fill. Dated to determine whether deposit represents prehistoric occupation, hitherto not discovered at site. Coll 1975 by Saržoski \& Gebhard; subm by E M Davis, this lab, \& E R Gebhard, Dept Classics, Univ Illinois at Chicago Circle, Chicago, Illinois. Comment (EMD\&ERG): corrected date of $1100 \pm 142$ $\mathrm{BC}$ indicates prehistoric age.

\section{Tx-2454. Stobi 14X73; Theater}

$1710 \pm 60$

From midden fill in S scarp of E Parodos of Theater, Strata 14 \& 15. Deposit represents dump after abandonment of theater; numerous coins in fill indicate middle to late 4th century AD. Dated to see if charcoal date agrees with coin date. Coll 1973 and subm by E M Davis. Comment (EMD): corrected date of AD $250 \pm 136$ agrees with coin date, but suggests charcoal may be earlier. Numerous such dates are needed to test relevance of dates on midden charcoal.

\section{Pizzica Series I, Italy}

Charcoal from coffins, Pizzica site, $3 \mathrm{~km}$ NW of Metaponto Scalo, Pizzica Pantanelle area, S Italy $\left(40^{\circ} 23^{\prime} \mathrm{N}, 16^{\circ} 35^{\prime} \mathrm{E}\right)$. Coffins and bodies were burned in earth. Dated to determine whether this unusual burial method was ancient or recent. Coll 1974 and subm by J C Carter, Dept Classics, Univ Texas, Austin.

\section{Tx-2286. Pizzica P2.74.100W}

$2320 \pm 60$

Sq B4, Tomb 1, 40cm depth.

\section{Tx-2287. Pizzica P2.74.106W}

$2180 \pm 60$

Sq B4, Tomb 2, 40cm depth.

General Comment (JCC): dates indicate graves belong to time of decline of Greek colony of Metaponto (late 4th century $\mathbf{B C}$ ), before later partial revival under Roman rule. Burning of bodies follows Greek practice to prevent spread of contagious disease, which may have played a part in decline of city. 


\section{REFERENCES}

Alexander, R K, 1974, The Archaeology of Conejo Shelter: A study of cultural stability at an Archaic rockshelter site in south western Texas: PhD dissert, Dept Anthropol, Univ Texas, Austin.

Bastian, Tyler, 1969, The Hudsonpillar and Freeman sites, north-central Oklahoma: Univ Oklahoma, Oklahoma R Basin Survey, Archaeol site rept no. 14.

Behrens, E W and Land, L S, 1972, Subtidal Holocene dolomite, Baffin Bay, Texas: Jour Sed Petrol, v 42, no. 1, p. 155-161.

Bell, R E and Baerreis, D A, 1951, A survey of Oklahoma archaeol: Texas Archaeol \&. Paleontol Soc Bull, v. 22, p 7-100.

Burne, R V, 1974, Deposition of reef-derived sediments upon a bathyal slope: The deep off-reef environment, north of Discovery Bay, Jamaica: Marine Geol, v 16, p $1-19$.

Damon, P E, Ferguson, C W, Long, A, and Wallick, E I, 1974, Dendrochronologic calibration of the radiocarbon time scale: American Antiquity, v 39, p 350-366.

Dibble, D S and Lorrain, Dessamae, 1968, Bonfire Shelter: Texas Memorial Mus, misc paper no. 1.

Frank, R, 1971, The clastic sediments of the Wellington Caves, New South Wales: Helictite, v 9, no. 1, p 3-26.

Harrington, M R, 1932, The Kachina Rockshelter in Nevada: Masterkey, Southwestern Mus, Los Angeles, v 6, p 149-151.

Hartley, J D, 1974, The Von Elm Site: An early Plains-Woodland complex in northcentral Oklahoma: Univ Oklahoma, Oklahoma R Basin Survey, Archaeol site rept
no. 28.

Hester, T R, 1971, Archaeol investigations at the La Jita Site, Uvalde Co, Texas: Texas Archaeol Soc Bull, v 42, p 74-76.

Texas: 1975, Late prehistoric cultural patterns along the lower Rio Grande of Texas: Texas Archaeol Soc Bull, v 46, p 107-126.

Hester, T R and Hill, T C, Jr, 1972, Prehistoric occupation at the Holdsworth and Stewart Sites on the Rio Grande plain of Texas: Texas Archaeol Soc Bull, v 43, p 33-65.

Texas. 1975, Some aspects of late prehistoric and proto-historic archacol in southern Hill, T C, Jr and Hester, T R 1971, Isol, Univ Texas at San Antonio, spec rept no. 1. Hill, T C, Jr and Hester, T R, 1971, Isolated late prehistoric and archaic components at the Honeymoon site (41 ZV 34), southern Texas: Plains Anthropol, v 16, no. 51, p. $52-59$.

1973, A preliminary report on the Tortuga Flat Site: A protohistoric campsite in southern Texas: 'Texas Archaeol, v 17, no. 2, p 10-14.

Keller, J E, 1975, The Black Dog Village Site: Texas Hwy Dept Pub in Archaeol, rept no. 5 .

Layton, T N, 1972, Lithic chronology in the Fort Rock Valley, Oregon: Tebiwa, v 15, p $1-21$.

Lundelius, E L and Davidson, Billy, 1975, Late Pleistocene vertebrates from Laubach Cave, Texas: Abs with programs, South Central sec, 9th ann mtg Geol Soc America, v 7, no. 2, p 211-212.

Lundelius, E L and Turnbull, W D, 1973, The mammalian fauna of Madura Cave, Western Australia, Pt I: Fieldiana, Geol, v 31 , p 1-35.

Mallouf, R J, 1976, Archeol investigations at proposed Big Pine Lake, 1974-1975, Lamar and Red R Counties, Texas: Texas Hist Comm, Archeol Survey rept 18.

Moore, C H, Graham, E A, and Land, L S, 1976, Sediments and sediment dispersal patterns on the deep fore-reef and island slope of north Jamaica: Jour Sed Petrol, v $46, \mathrm{p}$ 174-187.

Prewitt, E R, 1974, Archeol investigations at the Loeve-Fox Site, Williamson Co, Texas: Texas Archcol Survey Research rept no. 49.

Rohrbaugh, C L, 1973a, Hugo Reservoir 3: Univ of Oklahoma, Oklahoma R Basin Survey, Archaeol site rept no. 24. 1973b, Kaw Reservoir: The southern section: Univ of Oklahoma, Oklahoma R Basin Survey, Archaeol site rept no. 25.

R Basin Survey, Archacol site rept no. 27. 
1974b, Radiocarbon dates from Kaw and Hugo Reservoirs: Oklahoma Anthropol Soc Newsletter, v 22, no. 2, p 2-8.

Rusnak, G A, 1960, Sediments of Laguna Madre, Texas, in: Recent sediments, north west Gulf of Mexico, a symposium: Am Assoc Petroleum Geologists, p 153-196.

Scholl, D W and Stuiver, M, 1967, Recent submergence in south Florida: a comparison with adjacent coasts and other eustatic data: Geol Soc America Bull, v 78, p 437-459.

Schubert, C and Valastro, S, Jr, 1974, Terrazas Cuaternarias de la Orchila dependecias federales: Acta Cientifica Venezolana, v 25, Supp no. 1, p 41.

1976, Quaternary Geology of La Orchila I, central Venezuela offshore, Caribbean Sea: Geol Soc America Bull, v 87, p 1131-1142.

Schubert, C, Valastro, S, Jr, and Cowort, J B, 1975, Evidencias de levantamiento Reciente de la Cordillera de La Costa Central: Informe Preliminar: Acta Cientifica Venezolana, v 26, Supp no. 1, p 2.

Story, D A, 1966, Archeological background, in: Story, D A and Bryant, V M, Jr, eds, A preliminary study of the Paleoecology of Amistad Reservoir area, Texas Archcol Salvage Project, p 7-30.

Weir, F A, 1976, The Central Texas Archaic: PhD dissert, Dept Anthropol, Washington State Univ, Pullman.

Wilkinson, B H, 1973, Matagorda I, The evolution of the Gulf Coast barrier complex: PhD dissert, Dept Geol Sci, Univ Texas, Austin. 